Historic, Archive Document

Do not assume content reflects current scientific knowledge, policies, or practices. 

62,69

LUDHXXI,

\section{SEED BUYER'S GUIDE 1926}

TREEMAN \& MUNGER

PERRY, OKLAHOMA

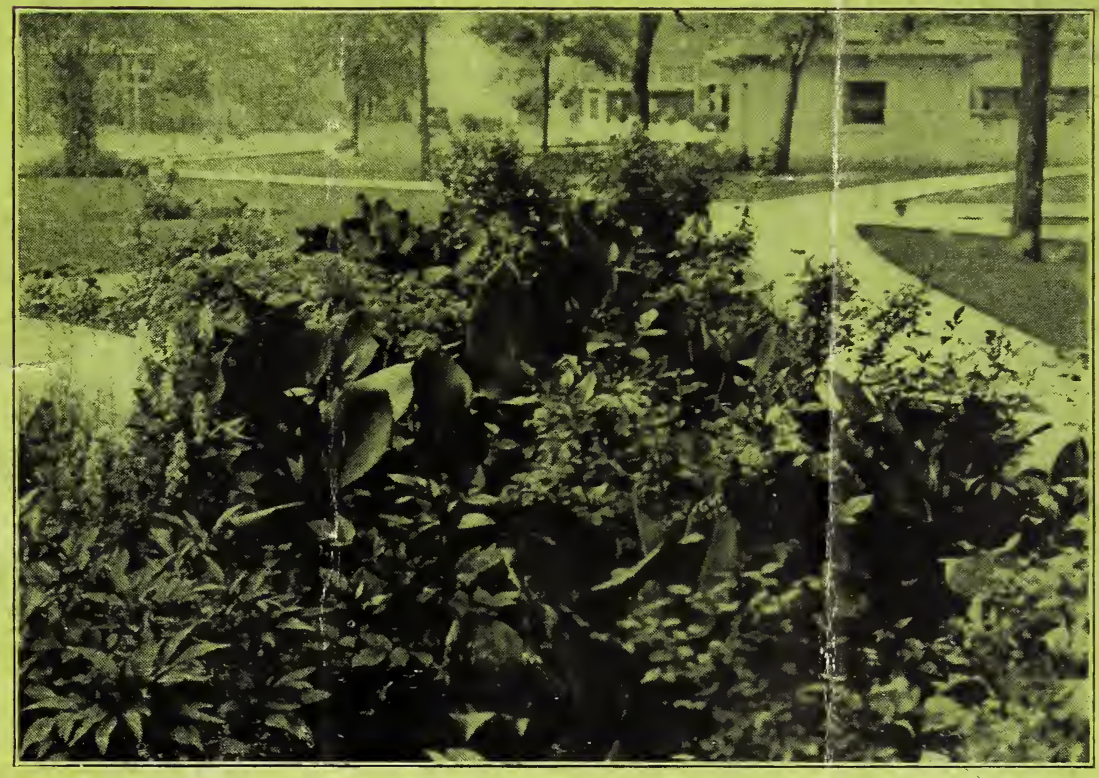

View in Court House Park, Perry, Okla.

Bed of Beautiful Canna, "Uncle Sam;” With Lantana, Vinca, Spirea and Other Annuals and Perennials in the Foreground

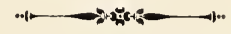

A Beautiful and Productive Oklahoma and Noble County is Our Ambition 


\section{"We Reap What We Sow"}

The County Agent pulled up his flivver in front of the Seed Store just as Jim Briggs finished loading a sack of seed on his truck. "Hello, Jim," said the county agent, "I see you've been buying some hay." "Why no," said Jim, "I don't have to buy any hay as a prule-grow all I need myself. Just been buying some seed." "May look that way to you, Jim," came the reply, but if you ask me, I'd say that what you've really bought is a crop of hay of some variety. Of course, you've got to sow it first and wait for it to grow and then cut it and take it in, but your whole harvest, good or bad, is tied up in that bag just the same. You'll harvest what you sow, won't you?', went on the county agent, "And you can't figure on harvesting anything that isn't already in that bag can you?" "Well, I guess you're right at that," said Jim. "Never thought of it quite that way before." The county agent chuckled. "Keep that in mind Jim, the next time you buy a bag of seed. It's the harvest in the bag that counts. Come over to my ofíice sometime and I'll show you through a high-powered microscope a lot of seed samples I picked up around the county last fall. You'll be surprised to see the kind of harvests some folks are going to grow !'-Ex.

Jim Briggs is a farmer. Farming is his business. He is interested in it. It is his means of laying by for old age. It is an honorable calling, that of farming, as old as the world and the most valuable for the world. Progress in farming has meant a strong demand for better seed, more varieties, types suitable for every climate. The duty of the seedsman is to provide pure types, strong types, which will stand climatic conditions. Let lis help you in your farming and gardening by providing seed we know through farmer experience will stand the test.

For the past six years we have made every effort in our power to secure the best seed, garden and field, for our trade. Our growing business indicates that this effort on our part is appreciated by the farmer and gardener. Every now and then, however, due to some unforeseen eause, weather condions, dry or wet, causes some loss in the planting of any seed, whatever its nature. Where it is possible we do our best to make any failure good, that is known to be due to seed conditions. If you are dissatisfied at any time, please let us know, the underlying causes and we shall gladly make amends.

\section{TREEMAN \& IUNGER, STEDSMEN}




\section{Conkey's \\ THE ORIGINAL

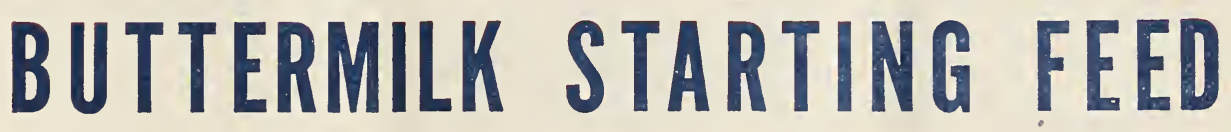 \\ Raises Husky Chicks}

A Ready Prepared Mash for baby chicks and all self-feeding young fowls. This remarkable feed-originated by Conkey and prepared through processes controlled and used exclusively by Conkey is a complete ration-containing all the elements needed for afely starting baby chicks, ducklings, goslings, poults, guineas, pheasants, etc.

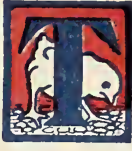

HIS superior chick mash was the first commercial poultry feed containing buttermilk - that is why we call it the only ORIGINAL buttermilk starting feed.

Conkey's did not "just happen" - it is a scientifically-balanced feed as clean and wholesome and as conscientiously-prepared as "inf ant food." Selected, plump grains, ground to proper fineness, are combined with other ingredients so as to make the feed readily digestible, palatable and nutritious. TASTE it, SMELL it, that's the way to judge a chick feed.

Conkey's carries buttermilk in just the right proportion as an aid in prevention of bowel troubles, White Diarrhea, "leg weakness," etc. The buttermilk is Semi-Solid buttermilk, blended with the other ingredients by the ORIGINAL process in such a way as to preserve the appetizing, tonic, and other properties of the newlychurned product.

The moisture in the buttermilk is drawn off by the exclusive Conkey process in such a way as not to subject it to the terrific heat usually required in "drying" buttermilk.

Lactic acid in buttermilk is described as an "Intestinal Broom" which sweeps away unfriendly bacteria and disease germs in the delicate digestive tract. Buttermilk is also rich in one of the vitamines necessary to growing birds. It is a wonderful appetizer, aid to digestion, and flesh builder.

However, it is not the buttermilk nor the other ingredients alone that causes people to declare that thei chicks grow twice as fast on Conkey's.

\section{GUARANTEED ANALYSIS}

Crude Protein, 14\%; Crude Fibre, 4\%; Crude Fat, 3\%; Nitrogen Free Extract, $56 \%$; Carbohydrates, $60 \%$.

\section{Ingredients}

Semi-Solid Buttermilk, pinhead oatmeal, a special wheat middlings, whole corn meal, corn feed meal, granulated bone and blood flour.

It is not the buttermilk alone that protects the chicks from disease during the first critical eight weeks. The secret is in the combination of these materials by the Conkey method-the balancing of the ration, as Conkey alone knows how.

Don't be influenced by "cheaper" imitations labeled "buttermilk" - that word may be used to deceive unwary buyers-to cover up a multitude of "sinful" grains, mill sweepings, poisonous weed seeds, musty screenings, worthless by-products, or other poor material having little or no nutritive value.

Conkey's is so palatable that one poultryman said it ought to be used for "breakfast food." One woman wrote: "My chicks just love Conkey's. It is so tasty, and my, how they do grow! Better still, we didn't have a single loss in the present hatch, no White Diarrhea or other bowel troubles like before we began using Conkey's."

\section{FEED IT FIRST 8 WEEKS}

Conkey's is all the chicks need the first eight weeks except greens. charcoal, grit, clean water and some fine scratch grains in the litter for exercise. Give grit and water from the start. During the second week add green stuff and in the fourth week finely

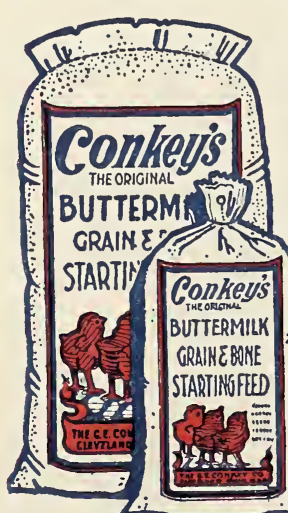
cracked grains, like Conkey's Chick Grains.

Packed in convenient sizes from $21 / 2$ lbs. up. Buy $11 / 2$ lbs. for every chick. Ask or write for prices.

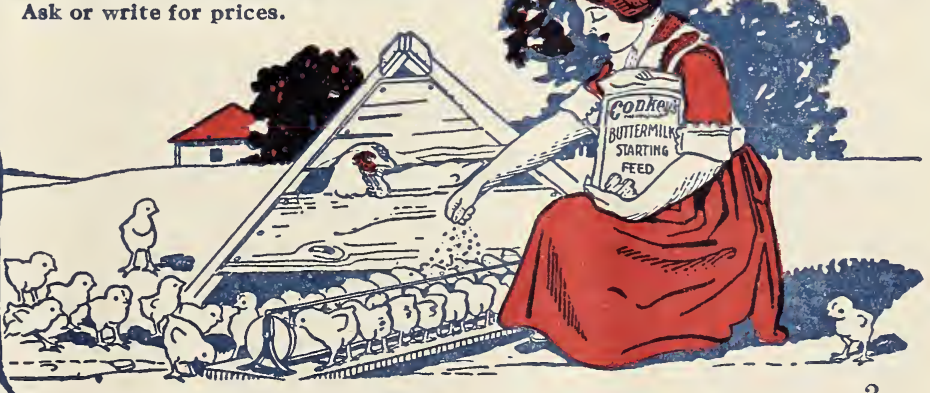




\section{6 ORDER SHEET

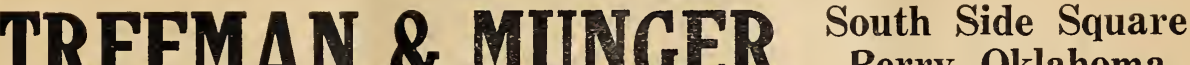 Perry, Oklahoma}

\section{All members of one family should order under one name.}

Personal Checks From Unknown Patrons Will Be Cashed Before Order is Executed If you have changed your address since last ordering, please give old and new address

Please forward the following as per terms of your Descriptive Catalogue

Name

(Ladies, please use prefix Miss or Mrs., the latter use

IIusband's initials. Write name and address very plainly)

Post Office

R. F. D. No._-_Box No._-_Street. . . . . . . .

Express Office

Freight Depot

County

State

How Ship? [ [ $\left.\begin{array}{l}\text { State on this line whether want- } \\ \text { ed by Mail, Express or Freight }\end{array}\right]$

If to be sent by Mail be sure to include Postage on goods not postpaid. See inside front cover.

For Postage and Express charges see inside back cover of Catalog

\section{HOW TO SEND REMITTANCE}

Never send bills or currency in a letter. If necessary to do so be sure to REGISTER IT. The safest form of remittance is a Check, Post Office or Express Money Order.

QUANTITY | NAMES DF SEEDS, BULISS, ETC. WANTED 1 PRICE

TRELMAN \& MUNGRR Give no warranty, express or implied, as to description, purity, productiveness or any other matter of any seeis, bulbs, plants, shrubbery or nursery stock they sell, and they will not be in any way responsible for the crop. If the purchaser does not accept goods on these terms, they are to be returned at once. 


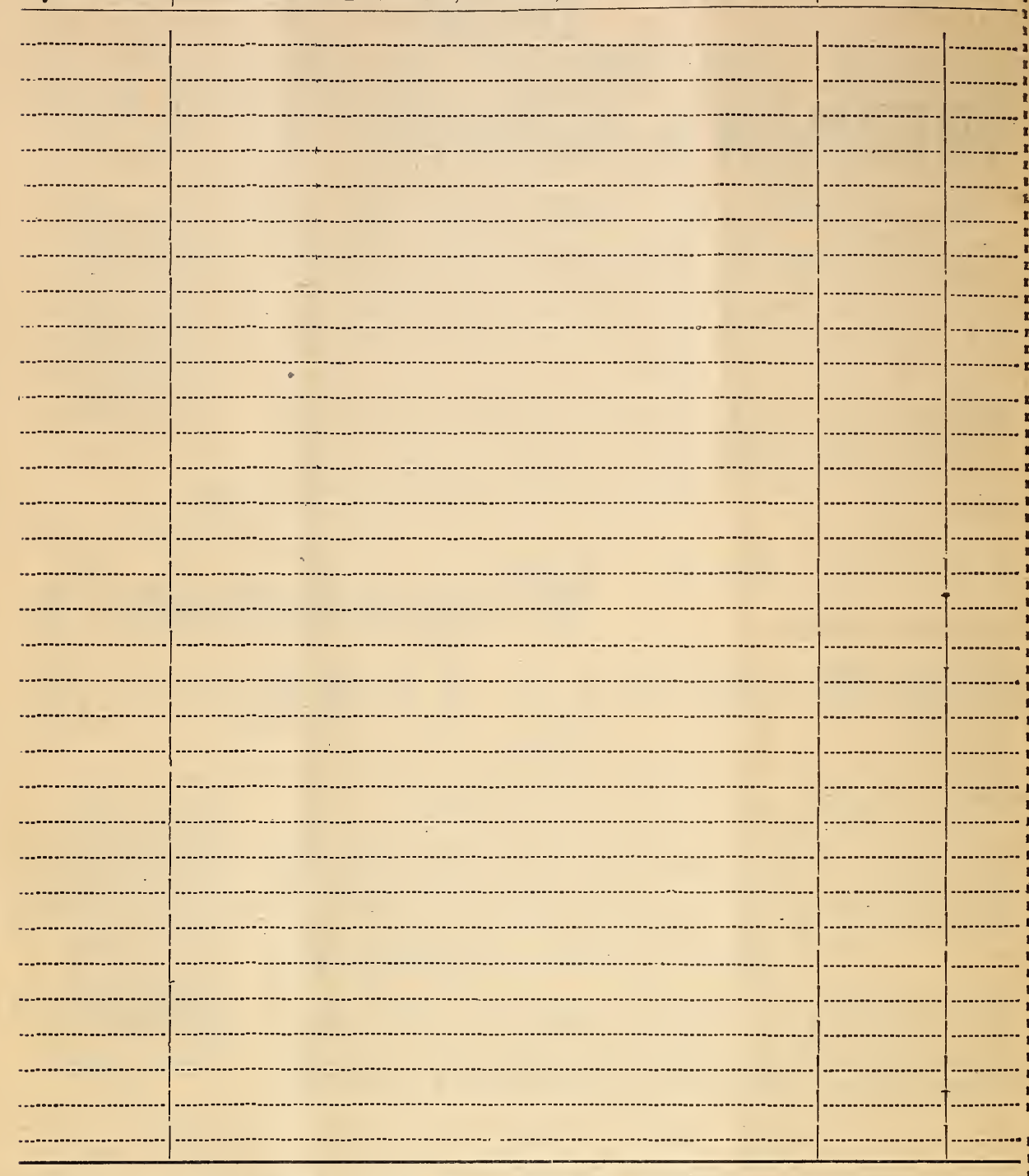

SPECIAL NOTICE: We shall esteem it a great favor if you will give us in the ers or Truck Farmers among your acquaintances. We wish to send them our SEED ANNUAI.

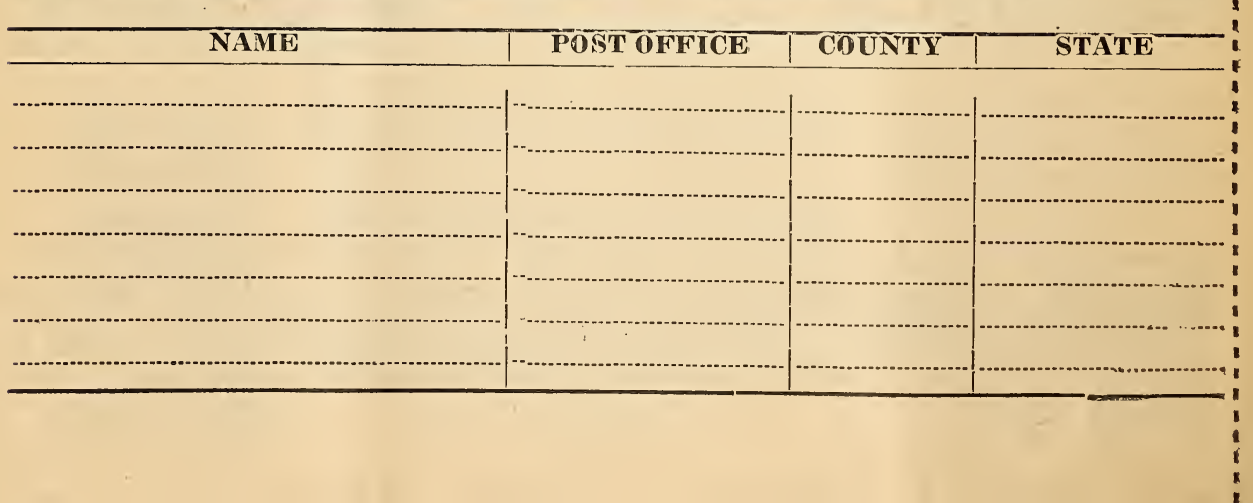




\section{GARDEN PLANT ORDER SHEET}

Please order all garden plants on this sheet

Prices quoted are delivered prices to your home, except in large quantities where we quote special prices. Kindly ask for quotations on large quantities of any garden plants needed, in ANY QUANTITY. WE CAN FILL YOUR BILL, HOW EVER LARGE.

\begin{tabular}{|c|c|c|c|c|}
\hline Bermuda Onions: & & 100 & 500 & 1,000 \\
\hline Crystal White & Wax... & $15 c$ & $75 c$ & $\$ 1.50$ \\
\hline Yellow & 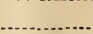 & $15 c$ & $75 \mathrm{c}$ & $\$ 1.50$ \\
\hline
\end{tabular}

Ask for special quotation on basket lots of 6,000 plants, and in large quantities. We have the onions.

Frost Proof Cabbage: $10040 \mathrm{c} ; 500 \$ 1.75 ; 1.000 \$ 2.50 ; 5,000 \$ 7.50$.

Early Jersey Wakefield; Early Flat Dutch and Charleston Wakefield.

Pepper: Two inch potted plantes $10 \mathrm{c}$ each, $\$ 1.00$ per dozen. Transplanted plants $15 \mathrm{c}$ per dozen; $\$ 1.25$ per 100. Ruby Giant; Chinese Giant; Bull Nose and Cayenne.

Sweet Potato: $10050 \mathrm{c} ; 500 \$ 2.25 ; 1.000 \$ 4.00$. Write for prices on larger quantities.

Nancy Hall, Bradley Yam, Porto Rican.

Egg Plant, New York Imp. Purple: Two inch potted plants $10 \mathrm{c}$ each ; $\$ 1.00$ per dozen. Transplanted plants $15 \mathrm{c}$ per dozen; $\$ 1.25$ per 100 .

\section{USE THIS ORDER BLANK}

(Town)

(State)

TREEMAN \& MUNGER,

(Date)

Perry, Oklahoma

Enclosed please find $\$$ .for which please send me the following.

NO. $\mid$ NAME $\mid$ A

(Print Name in Full)

Make your order NOW. We will ship plants at the proper planting time. You will find that this plan will assure you of splendid planting stock at the proper time for planting and it will further assure you of the highest class stock. For practically everything is grown in our greenhouse under very best growing conditions.

All shipments made by express are at your expense. Parcel post shipments, not over five pounds, at our expense.

TREEMAN \& MUNGER Give no warranty, express or implied, as to description, purity, productiveness or any other matter of any 3 seeds, bulbs, plants, shrubbery or nursery stock they sell and they will not be in any way re8 sponsible for the crop.If the purchaser does not accept goods on these terms, they are to be returned at once. 


\section{Our New Floral Department}

We are growing all the plants which we are listing. This gives you the very best stock, properly grown. properly packed. and at the time you want them for outdoor or box planting. Your order will receive the very best attention and preparation.

\section{USE THE ORDER BLANK}

Alternertheria, Joseph's Coat. Two inch pots, 10c each, $\$ 1.00$ per dozen.

Asters. Finest mixed colors, two inch pots. 10c each, $\$ 1.00$ per dozen.

Black Fyed Susan. For porch boxes, two inch pots, 15c each.

Coleus. Christmas Gem. Many other colors two inch pots 10c each, \$1.00 per dozen.

Daisy. Mother's Favorite, 20c each, 50c each. 4-inch pots.

Firecracker Plant. Porch boxes, bedding 15r each; \$1.50 per dizzen.

Ferns: Plumosus, Sprengeri, Boston, 15? 35c. 5\%. and \$1.00 each.

Geranium. White, Pink, Salmon. Red “Fnidl." 15c. 25c. 50c, \$1.00

Lantana. Red( Orange. White. Yellow, Purple, 15e two inch pots. $\$ 1.50$ per dozen.

ORDER ON THIS SHEFT. We will immeliately send you another blank for future use.
Petunia: Double, White, Colors, 10c each? $\$ 1.00$ per dozen.

Petunia. Single, Rosy Morn, Pink, Califomnia Giants, many colors, 10c each, \$1.00: per dozen.

Salvia. Two inch pots. 10c each $\$ 1.00$ per, dozen: 3-inch pots. $15 \mathrm{c}$ each, $\$ 1.50$ per dozen.'

Santr Lina. Border Plant. For edging, walks and beds. everlasting; two inch pots, 10m each: \$1.00 per dozen.

Pansw hlooming, two inch pots, 10c each.' 75. ner dozen.

Ph!nv. Perennial. many molors, two inch' rots. 15n each: \$1.50 per dozen.

Snandragnn. Mixed colors, two inch pots. 1fo each: \$1.00 per dozen.

Varbana. Blue. purple, white, pink, red. ins each. \$1.00 per dozen.
(Towh)

(State)

TREEMAN \& MUNGER

Perry. Oklahoma

(Date)

Enclosed please find $\$$. the following: for which ship us by

(freight, parcel post or express)

NO. NAME

Very truly yours,

(Print Name Here in Full)

Make vour arfler now. We will send rlants to vou at the proper time for successful plant-i ing. Tuse this blank also for any seed you may need.

All shipments made by express are at your expense. We prepay parcel post hsipments not over five pounds. 


\section{ASPARAGUS}

'The ground should be well prepared by deep spading, with barnyard manure, well rotted, worked in the soil. It is usually two years from time of sowing until cutting. The surest method of getting quick results is setting two-year loots.

\section{ASPARAGUS SEED}

Conover's Colossai. The standard variety; of large size, tender and of excellent quality. Uunce $15 c$.

\section{ASPARAGUS ROOTS}

Conjer's Culussai, 2 yeai roots. ir.ov; per dozen 25c.

\section{BEANS}

\section{Except winere noteả, all Beans 25c pe $i^{\circ}$ pound; 7 pounds $\$ 1.50$}

Beans are easily killed by frost, and rot in the ground readily when the soil is cold and wet. Du not plant until all danger of frost is past or the ground can be easily workue. 'ioo much fiesh stable manuice will cause a rank, heavy growth without pod formation. More Lean crops are ruined from this cause alone than all others. Do not blame the seed, if this occurs. Shallow cultivation is necessary at all times and cultivatios should be compietely stopped after bushes begin to bloom. l'ick the vines clean of all mature pods regularly in vrder to continue succession of blooming.

\section{BUSH BEANS, Green Pod Varieties}

carly Improved Red Valentine. For snap beans there is no variety more certain to bear under adverse conditions. The pods are or medium length, about $4 \frac{1}{2}$ inches.

Lung Yellow, six Weeks. Pods long, stralyut, thick, tiat in shape, of good quaitty when young; fair when matured. Reauy for prcking $4 \bar{y}$ days from planting.

Extra Early Keiugee. Keady to eat to uays from pianting. Pods round, solid, tenuer, of excellent quality.

fiefugee, or 1,000 to 1. A late variety man ciopier, greatiy used for late plantulo anu very desirable for canning purposes.

Giant Stringless. A very stocky, hardy vine; pods long, round, of exceptionally tine quality and stringless throughout its entire growth. Very prolific.

Burpee's Stringless Green Pod. Develops pod to edible condition in 42 days. The pous are absolutely stringless; it is one of the very best beans for Oklahoma conditions; a splendid canning variety.

Longfellow. An ideal snap bean, producing a crop of long, straight, solid, fleshy pods, averaging $61 / 2$ inches long, wonderfully tender and brittle, without a trace of string when broken, excepting when pods are quite old. It is an extra early variety and stringless; ideal for canning purposes.

\section{WAX PODIED BEANS}

Davis White Wax. Pods are long, meaty flat, of a beautiful yellow and fair quality. The dry beans are splendid cookers. Really should be grown more for dry beans than it has, for it is very productive.

Imp. Golden Wax. Rust-proof, an improvement of the Golden Wax. Pod semi- 10u11d, of sood quality and has no string. 47 wing. vile of the reliable sorts for our use.

r'oinific Black Wax. The old sitandard watck wax veall. It is so good that no garden is wir. iece without it. Stands our weather coinatiuns better than almost any other vatecy, and can always be depended on to muke a crop under all conditions.

Leonard's Webber Wax. One of the best wax-podded sorts ever introduced. It is extensively used by the city market gardeners, prolific, of splendid eating qualities. While it has not been planted to any extent here, it is because its qualities are not well known. 'i'ry a pound this year and satisfy yourself that it is a real bean.

Michigan White Wax. This splendid variety can be best described as a white seeded Golden Wax. It is very early and very productive. The seed is pure white and it makes an excellent cooking bean. By its use the hame garden can be made to produce your own beans for winter use. Don't fail to plant this bean.

\section{DWARF LIMA BEANS}

Burpee's: The only bush type of the true luscious, large Lima. It is pronounced oy all judges to be the best of the lima beans. Bushes 18 to 20 inches, of stout growth and erect. It is an immense yielder. 30c to

Henderson's Bush Lima. This is a bush form of the small Sieva Lima, most productive of all. $30 \mathrm{c} \mathrm{no}$

Fordhook Bush Lima. Vines strong, erect. A desirable sort. 30c it

is a general favorite wherever grown, on ac-

Large White Lima. The larg white lima count of its productiveness and flavor. 30c it 


\section{POLE BEANS}

Kentucky Wonder. Too much cannot be said in praise of this pole bean for use in our climate. Wonderfully productive, long, green pods of delicious flavor; growing and maturing beaus under almost any weather condition. Planted along fences it will outyield any bean grown in Oklahoma. Try Kentucky Wonder and be convinced that it is the supreme pole bean for our use. 25c $\mathbf{1 6}$

Carolina Sieva Pole-Lima Bean. A sure crop variety of the climbing lima. 40c $\mathbf{1 0}$ 16

Corn Hill Cut Short: A fine climber. 30c

\section{CABBAGE}

\section{All Cabbage Seed 20c oz., 4 oz. 75c; 1 ib $\$ 3.00$}

Culture: Cabbage grows successfully here only with very early planting. It cannot withstand the extremely dry weather we have; but it will endure if properly tempered the frosts and cold weather we usually have in the spring. Six years ago anyone planting cabbage here in February was thought-well, mildly, foolish. But the wonderful growth made by Vermillion's cabbage in the severest weather we have at that time, convinced the most skeptical there is something to frost-proof cabbage. Any seed can be made frost-proof plants by properly tempering the plants ruring their growing period, which, preferably, for early and sure cabbage should be during the winter months and cold frame grown. However, as most of us are unable to care for a cold frame, a certain method to secure early cabbage is to buy the plants Let us state right here that sometimes the most wilted looking plants, most scurvy looking specimens, will produce the surest stand. All of the primary leaves will shed; and as long as the heart is good there is every chance for every plant put out to make good. This is from actual experience with frost-proof plants from the Atlantic Coast and Texas grown right in our own neighborhood and from men and women who would not misrepresent the matter. Another point in favor of frost-proof cabbage is that it is up and out of the way before the cabbage worms have an opportunity to ruin them. Plant them this year. Grow your own plants or buy the plants from us.

Early Jersey Wakefield. The seedmen from whom we buy our seed have exercised great care in the growing of this most important variety. You can be assured that you are getting the very highest type seed from high type plants when you buy of us.

Early Winningstadt. A second early variety. Almost as good as Wakefield in the peaked head cabbage.

Early Dwf. Flat Dutch. An early cabbage of good size. Heads flat and solid.
Early Drumhead. A second early fllatbearled variety. Good solid head, large, compact, crisp and tender.

Glory of Enkhuizen. An excellent mid. season variety. Recommended wherever grown as worthy of a place in the garden.

Prem. Late Flat Dutch. This variety is a standard of all sections for late use. Adapted to a more varied climate than any other cabbage of which we know. field.

Copenhagen Market. As good as Wake.

\section{FROST-PROOF CABBAGE PLANTS}

We have arranged with one of the biggest growers in the United States for our supply of cabbage plants. They can be secured for February planting by sending in your order im. mediately. These plants are grown on the Atlantic coast; and while they may reach you in a dried looking condition, pay no attention to that but put them out.

They are frost-proof because they can stand temperatures down to 20 degrees above zero without being injured. Snow may fall on them, rain may freeze about them, but they will not be harmed so long as the temperature does not go below 20 degrees. These plants are grown for us in the South, in the open field, in the winter and early spring, where low temperatures restrain their growth and give them their great powers of resistance.

\section{Important}

To get the full benefit of their frost-proof and early heading qualities, these frost-proof plants must be set out at least a month to six weeks earlier than you would set out homegrown cabbage plants. When the weather is cold the tops do not grow, but the roots develop and are ready to boost growth when spring weather arrives. ou can count on fully matured heads two or three weeks before you would get them with hot-house or cold-frame plants. 


\section{Early Crops Mean Bigger Profits}

Every week's time at the beginning of the season makes a big difference in prices. Vegetables aread of season bring 2 and 3 times the prices of those which come a few weeks later. By using our frost-proof plants you are sure of making a good profit over and above all costs. More than that, you will probably get DOUBLE THE USUAL CROP. Our plants are grown from such carefully selected seed that practically all of the plants form good heads. They frequently yield more that double the number of pounds you would get from oriinary plan!s.

Let us have your onder now, together with the date you wish to receive the plants. An farly order means that neither of us will be disappointed and guarantees that you will get unusual cabbage profits this year. Orders filled from December 1 to ay 1 . Three varietieseach one an excellent strain: Early Jersey Wakefield. Farly Charleston Large Type Wakefield and Early Flat Dutch.

PRICES: By parcel postpaid, in lots of 100 . 200, 300 or 400 plants at 30c per 100 plants; 500 plants for $\$ 1.50 ; 1,000 \$ 2.50$. Over 5.000 lots, $\$ 1.50$ per 1,00, f. o. b. Perry. Okla.

\section{TABLE BEETS}

\section{All Beets 15c oz., $1 / 4$ ib $40 \mathrm{c} ; 1$ it $\$ 1.00$}

Culture: As soon as the soil can be worked in the spring, cover the beet seed, which usually contains two or more seeds, in rows 12 to 18 inches apart, 1/2 inch deep. Tamping the soil over the seed with the hoe will help conserve the moisture. Use 1 oz. of seed to 100 ft. of row; 5 or 6pounds to acre. The varieties which we are presenting are those which, during the past five years have given the bes tresults and most nearly meet all weather conditions here.

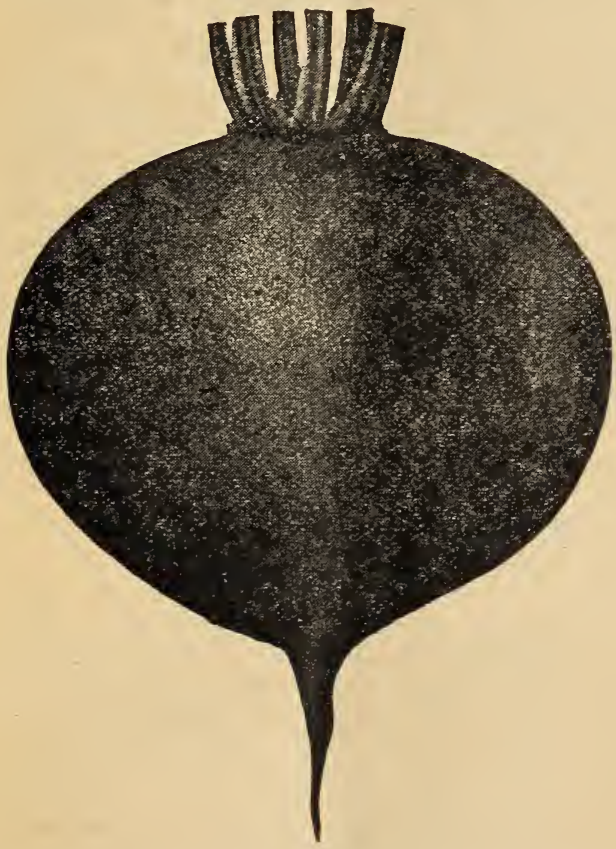

Leonard's Egyptian. This is the earliest and best selling beet for the store trade. It has been grown many years by market garrleners. Their growing it in preference to all otlers should be proof to the home garlener that it is worthy of a place in the average home garden.

Fariy Egyptian. The well known early variet,. Extra lark, flat, quality excellent.

Extra Early Blood Turnip. Very early and sweet, ringed red and white. A splendiil beet for the early garden.

Detreit Dark Red Turnip. Quality good sweet and tender; color deep red, turnip shaped. This is one of the best canning bcets grown. Three years' experience with it has shown that it is among the best beets for our climate and that it also is a splendid eanning beet.

Imp. Blood Turnip. An improved variety of the Early Blood Turnip of deep, blood red color; splendid for canning, fine form and color.

Swiss Chard. This is not a true beet; but its leaves are used for "greens." Cooked with mustard, spinach, or other wild greens, it is excellent. Of heavy growth and by cutting often can be kept growing for

EARLY IMPROVED BLOOD TURNIP-BEET green purposes a long time.

We can supply you with any plants you may want and all at as good prices as you will find in any seedman or nursery catalog. Let us know what you want and we will gladly get it for you. 


\title{
STOCK BEETS
}

Many people, especially tarmer's and poultry raisers, do not know that stock beets can be a sily and protitably grown here. We have seell during the past few years several rows of slock beets which yielued beets weighing tweive pounus. For stock feeding they are excellent. Lhe milk cows like them and will produce a greater and better flow of milk with their use. ror the chrckens they can be used the entire winter, furnishing a most excellent and succutent gieen food when greens are very scarce. They are easily grown, requiring the same care as laple beets. Une ounce will sow $100 \mathrm{ft}$. of row 5 to 6 pounds to the acre. Don't neglect (u) plant at least one pound this year. It will repay you many fold.

Imp. Mammoth Long Red. The largest and most productive variety. Immense crops can be grown from it. Per it 60c.

ivein Wanzreben. A true sugar beet, contailung a high percentage of sugar. We have

seen it growing here and used while quite young for table purposes. It will produce a high tonnage to the acre, yielding even here, a high percent oí sugar. Non't fail to plant some of these beets. Per 1b 75c.

\section{Uur Stock of Beet Seed is Absolutely New Crop Seed CARROTS}

\author{
All Table Carrots, 15c oz., 1/4 Ib 56c; $11 \mathrm{~b} \$ 1.50$
}

'Llhe carrot, whether used raw, fried, boiled or stewed, or used with other vegetables and meats, is not surpassed by any vegetable in nutritious qualities. Use $1 \mathrm{oz}$. seed to $100 \mathrm{ft}$. row, covering 1/2 inch deep later timnumg to 1 plant to every three or four inches. During the past tew years lile carrot has mace wonderful records for growth here-prior to that time it was stluom seen in home gardens. Aiso, do not neglect to plant the big varieties for poultry and slock reeding. 'L'hey are widely used where their fine qualities for feeding have been tested.

Chantenay. Tops medium size roots tapering but smooth and uniform; color deep orallge-red; uesh very crisp and tender. A heavy cropper and one of the best for the home garden.

Guerancie, or Ox Heart. Roots comparitively short but often reach a diameter ot $b$ ınches. H'lesh bright orange, fine grained aurl sweet.

Long Orange. The most popular sort for use on meliow soil. Large, deep orange, sweet and crisp.

Danvers. Grown largely for its adaptability to soil and weather conditions and productiveness. Flesh sweet, crisp and tender, of deep orange color. The most desirable surt for tight land.

Hutchinson. A greatly improved table carrot of better form than Danvers.

Large White Vosges. A pure white carrot, 0 to 7 inches long, 4 to $4 \frac{1}{2}$ inches at shoulder, tapering. Easily harvested. One of the heaviest producers for stock and poultry feeding. Don't neglect to plant at least $1 / 4$ acre to this important feed crop.

\section{COLLARDS}

A form of cabbage or kale much grown throughout the South. The colored poyulation of Oklahoma grow this vegetable extensively. Freezing does not injure but improves the quality.

Georgia. We offer the true white or green stem stock. 15c ounce.

\section{CAULIFLOWER}

Caulifiower has become too well known during the past few years to give an extended description of the vegetable. However, it iesembles cabbage in the necessity for early spring transplanting and will endure the same weather conditions that frost-proof cabbage will stand. Either plant seed in hot-bed, transplant to cold frame, or buy the plants early. We have the plants for sale during February and early March.

Snowball. Said to be the best for both very early and late planting. Head uniform of good size and solid. Pkt. 15c. Plants at market prices.

\section{CELERY}

While not many gardeners are successful with celery here, there are others using the self-blanching variety who, with weather conditions as they have been during the past few seasons, are successfully growing this import. ant addition to the table. Celery seed should not be planted as heavier seeds, but pressed in the ground, kept damp, at a temperature of about 60 degrees; then transplanted into deep rows which give the advantage of being able to throw the soil in to the plants. It must have plenty of moisture at all times; but do not cultivate while the plants are damp, as it causes rust.

Golden Self-Blanching. The best of all self-blanching varieties. Pkt. 10c. 


\section{SWEET CORN}

\section{All Sweet Corn 20c per 15; 2 ib 35c, except where noted}

We are not carrying an extensive line of sweet corn. Only those which the past six years' experience has shown are best adapted to use in Oklahoma. Planting time shourd start when frost is out of the ground, or, as a very good friend who has been buying our seed for years says: "When the buzzards first fly, plant corn." And through many years he has used this planting date and successfully grown corn when others have failed. Try his plan. It can't hurt anything and may make you as successful as he. We can recommend the following varieties for your planting:

Golden Bantam. A very early sweet corn with golden grain, very tender and of most excellent quality. Several years of experience with this corn has shown that it is of rapid growth, about four feet high, producing as many as six ears to the stalk.

Fxtra Early Adams. This is an extra early white variety, sweet and juicy.

Kendall's Early Giant. A customer's request for this corn several years ago was its first introduction here. It has proved to be an excellent corn. Early, very large and sweet.

Early Evergreen. This, to out way of thinking, is the best sweet corn ever introduced here. Our customers who have bought it during the past four or five years, call for more and more of Early Evergreen every spring. Pure white grains, deep, sweet and juicy. Ears eight tō ten inches in length. When planted early will mature roasting ears by the middle of June. The best for early market use.

Stowell's Evergreen. The standard main crop corn. Later than Early Evergreen, but its equal in every other particular. Plant both corns.

Country Gentleman. No home garden is complete without this corn. Very deep grain, sweet, juicy, grans very irregular on the cob but a sure cropper.

\section{CUCUMBER}

\section{All Cucumbers 15c oz.}

West India Gherkin. A very small, prickly sort, different from all others. Widely used for pickling.

Early Cluster. Vines vigorous, producing clusters of fruit. The best of the pickling varieties used here.

Green Prolific. A favorite for pickle growers. Widely used here.

Beston Pickling. Úsed for pickling and table.

Chicago, or Westerfield Piekling. Fruit me. dium length, pointed at each end. Color a deep green. For table and pickling.

Imp. Long Green. Fruit long and slim. not surpassed by any variety for quality. Table and pickling

Early Imp. White Spine. One of the best and main sorts for table use. The old standby in Oklahoma.

Davis Perfect. Dark glossy green, slim splendid keeper, the kind that sells best at the stores. This variety leads them all.

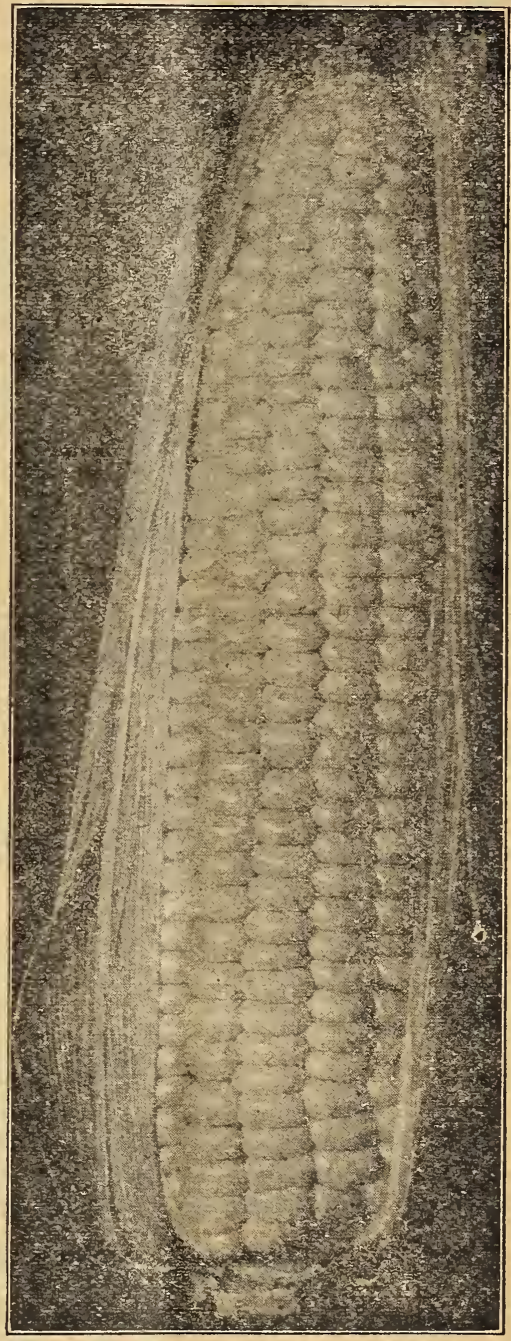

EARLY IEVERGREEN SWEET CORN

Hiondylie. A new sure crop cucumber of great merit. Fine table sort. 


\section{Egg Plant}

Egg Plant plants can be made to produce as splendid fruits here as is grown in the market regions of the far south. Transplanted in late April or May they will begin to bear by the middle of the summer and give a succession of fruit until after the first frost. They are delicious fried. The fruit is ripe when the blossom end shows indention when pushed with the finger. Pull, peel the fruit as one would an apple, slice, place in sall water solution for a short time, then roll in cracker crumbs and beaten egg. Fry in hot lard. Serve hot.

Six plants will bear sufficient fruit for the average family. PLANTS from $2 \frac{1}{2}$ inch pots ready to go. 10c each, \$1.00 per dozen. Uon't neglect planting this vegetable.

\section{Endive}

Used as a salad garnish. Can be grown in the lome in pans the entire year, or planted in garden in spring for summer use : or late summer planting will give this plant an opportunity to establish itself for the winter. It can be used in soups and when so wanted its acrid taste can be removed by blanching the plants. Uone by tying burlap about the plant.

Green Curled. Beautifully curled, tender and crisp. Oz. 15c.

\section{Kale}

This is one of the best vegetables grown, but is very little used here. It will endure the hardest winter weather, improving with severe freezing. Should be cooked as other regetables of like kind.

Dvarf Curled Scotch. Plant low and compact, large bright, deep green leaves, crimped until the whole plant resembles a bunch of moss. 1 oz. 10c; $1 / 4$ to $30 \mathrm{c} ; 1$ it $\$ 1.00$.

\section{Kohl Rabi}

Relative of the cabbage, although it looks like a turnip; can be treated as either. Planted eariy in spring, it will make edible growth befo"e the hot weather strikes it. Planted in the fall, as the turnip, will produce heavily. Don't neglect to plant this good vegetable. 20c oz.

Ea:ly White Vienna. An early variety ready for use within seventy days after planting. Should be used when bulbs are 2 to 3 inches in diameter.

Early Purple Vienna. Bluish purple, similar to above.

\section{BERMUDA ONION PLANTS}

The real value of the Texas Bermuda Onion, sweet and easily grown, is being more appreciated every day. Do not plant early while there is yet danger of frost. They will not stand it.

We offer the following varieties:

Crystal White, Yellow Bermuda. Both are exceptionally good.

Prices: 15c per $100,50075 \mathrm{c} ; 1,000 \$ 1.50 ; 6,000 \$ 7.50$

Extra large plants (these are splendid, averaging three times the size of plants usually sold.) 100, 25c; $1,000 \$ 2.50$.

PARCEL POST OR EXPRESS CHARGES PREPAID DIRECT TO YOU.

\section{SEED POTATOES}

We carry the following Irish Seed Potatoes; inspected stock conforming to the Oklahoma State Seed Law Inspection requirements: Cobbler, Early Ohio, Bliss Triumph.

All Seed Potatoes are subject to market changes, therefore no prices are quoted. Write us your requirements and ask for prices.

\section{SWEET POTATOES FOR BEDDING}

Sweet potato stock is hard to keep. Our stock all complies with the State Board of Agriculture requirements. We carry the following stock:

Nancy Hall, Red Porto Rican, Bradley Yam.

Sweet Potato slips are grown by ourselves. Inspectied by the State Board of Agriculture, complying in every respect with all requirements for safe stock. Prices subject to change without notice. 


\section{LETTUCE}

\section{All Lettuce except where noted 15e oz., $1 / 4$ if 60c: 1 it $\$ 2.00$ postpaid}

There is no need to give extensive planting directions for lettuce. It is too well known and universally used. However, lettuce can be planted here early in the spring, and in the late autumn and yield a splendid crop. We have been careful about the varieties which we are offering and know that those we have listed will give best results. This is true of the head lettuce, which unless planted early will not, cannot, make the heads so much esteemed. One planting head lettuce should unscrupulously thin the plants, giving them and opportunity to develop individually. In this way only can one be successful with head lettuce.

Blapk Seeded Simp. son. we have a tine strain of this popular loose-leaved sort.

Early. Curled Simpson, White Seed. It forms a close, com pact mass of curly, yellowish green leav. es. One of the very best for our use.

Prizehead. The name is misleading for it is a leaf lettuce. Color light brown on green base. A splendid variety, some of our customers will use no other. Very crisp and tender.

Denver Market. This is a fine, crisp headed variety. While it will not head here unless as indicated culture above, it does make fine leaf lettuce.

California Cream Butter. A grand, good butter lettuce.

Big Boston. Very large heads, making a splendid leaf lettuce here.

New York or Wonderful. One of the best of the curled or crisp heading varieties. Try it. 20c oz.

May King. Plant this lettuce for the earty growth. Outer leaves tinged brown but with heart a splendid crisp yellow.
Iceberg. A beautiful lettuce. Large curly leaves of bright, light green with very slight redlish tint at edges.

Paris White Cos. The best known and most popular of the Cos type. Heads should be tied with strips of cloth to force blanching. Probably the surest of the heading types here.

Hanson. One of the best varieties grown.

\section{MUSKMELONS \\ Write for Prices on Large Quantities}

The past seasons have proved conclusively that our Muskmelon Seed is as fine as can be bought anywhere. We have taken particular pains to buy only the very best, high tecting, true to name and true to type seed. The growers all over northern Oklahoma were exceptionally well pleased with our seed. If such a thing were possible, we have a better sirain of melons this year than ever before. The market gardener need not hesitate to place his faith in our seed either from a germination staldpoint or that of purity. WE KNOW THAT OUR SEED WILL GROW TRUE TO TYPE AND NAME. 


\section{Muskmelon Seeds}

411 seed except where noted 10c oz., $1 / 4$ it $40 \mathrm{c}: 1$ it $\$ 1.50$

IVe have encleavored to get trose muskmelons which are certain to do the best under our weather conditions. And we know that we have the very best true to type seed which can he bought.

Rockyford. This is the most important melon grown here. The vines are vigorous and productive. The fruit is oval, slightly ribber. densely covered with fine netting. Flesh green and very sweet.

bockyford 10-25. This melon is identical with the Rorkyforl exent. in color of flesh which is salmon tinted instead of green. Our stock of this seed cannot be surpassed for quality.

Nefted Gem. The best early molon known.

Early Nutmeg. A very early green fiesherl melon of excellent Havor.

Early Hackensack. Medium, to laige size, nearly round, deeply ribbed. The flesh is green, a little coarse but sweet and juicy.

Hackensack, or Turk's Cap. A very large or green fleshed melon.

Burrel Gem. The new Rockyford melon with golden meat.

Honey Dew. Fruits round, slightly oval, six to eight inches in diameter. Flesh light emerald green, skin smooth. This melon

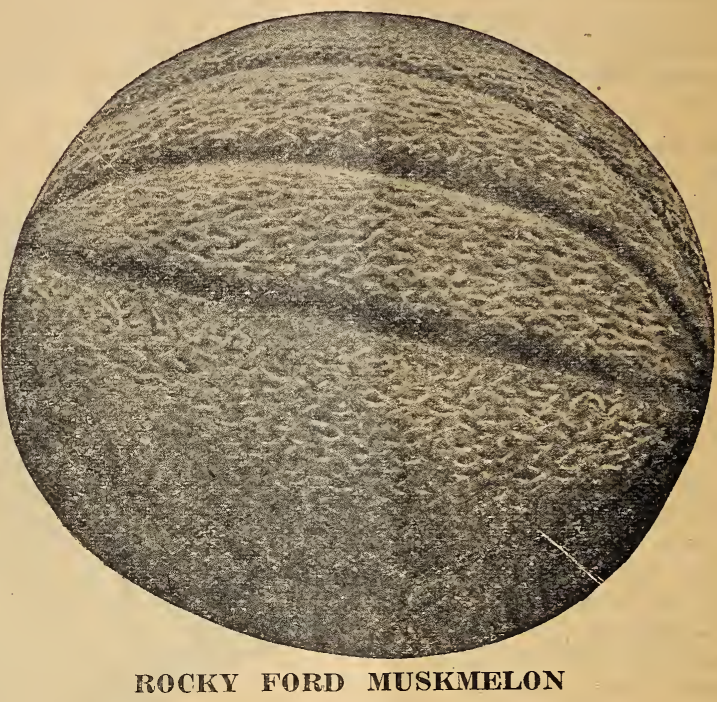

does remarkably well here. California grown.

Brnana. A long, salmon fleshed, smooth skinned variety of excellent flavor growing about 15 inches long.

\section{Attention Watermelon and Muskmelon Growers}

There is no better seed grown than we have. Varieties are true to name and type. We want to help the growers along the Salt Fork, Cimarron and Arkansas River bottoms this year by giving you the best seerls grown. A trial will convince you that it pays to buy our best seed. You know that poo rseed never pays. Therefore do not buy cheap seed becruse of the few cents saving, but buy the best, looking toward a real profit in Watermelons and Cantaloupes by having the very best seed possible to obtain. If you are a cantaloupe grower, rear our method of securing cantaloupes early. It will pay you. Buy our New Wonder waten melon seed.

\section{EVERY POULTRY RAISER KNOWS}

\section{The Value of Proper Equipment for Poultry Raising} ROYAL COAL BURNING BROODERS 500-1,000 Chick Capacity, Solves the Problem 


\section{WATERMELONS}

\section{All Melons 10c oz.; $1 / 4$ it $25 e ; 1$ th $75 c$; 5 th $\$ 3.00$. Special Prices on Large Amounts for Truck Growers}

Tre past season has proven conclusively that it pays the commerelal grower. as well as the home grower, to buy our best seed. It has taken several rears for us to fully acquaint ourselres with the type and quality of seed which is so necessary to successful growing. and with those melons which demant? and enjoy the best prices.

The grower, either for home or commercial use, is assured when our seed is used of buying the very best and highest germinating seed which can be secured. Our seed is raised for us under contract, by the largest growei of seed in the world. By a man who has grown seer for many years and enjoys the enviable reputation of "squareness" in "all his dealings. We feel, that selling seed grown by him to our trade, is the best guarantee we can give the g:ower.

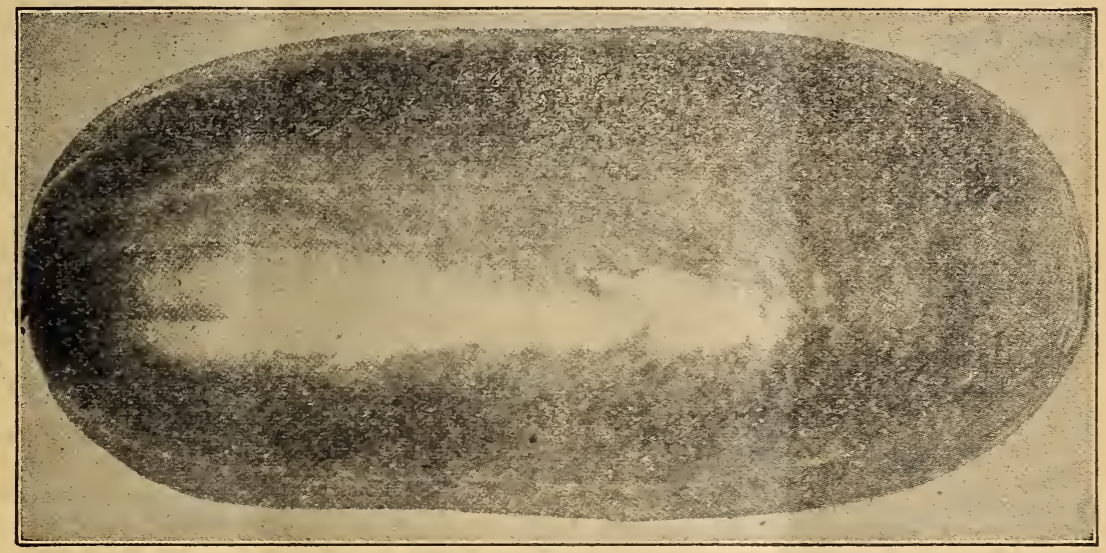

TOM WATSON WATERMELON

Tom Watson. Every grower knows the old favorite. Reliable bearer, always a good seller. Flesh rich red, very sweet, tenderly melting; long, dark green. Tom IV atson changed the market from a round to long melons.

Irish Gray. We brought the first seed of Irish Gray to Northern Oklahoma several years ago. The first year we gave the seed to a few growers. Since that time the viemand has been heavy for seed, with an increasing demand from the wagon and market trade. The melon is long, very heavy, light green skin, deep pink, tender, very sweet flesh. One of our customers, who grows for the market says that he shall specialize on Irish Gray from here on. Try a pound. Irish Gray will meet your highest approval.

Thurmond's Irish Gray. An improved type of Irish Gray.

Kleckley Sweet. $\mathrm{T}$ his is one of the finest melons grown for home use. Long, dark green skin, deep red, melting flesh, almost, with but one exception, the best for the home grower. Our seed is absolutely pure, true to type in every respect.

Halbert's Honey. When Halbert, of Texas dereloped his Honey watermelon, he gave to the home gardener the finest gift that anyone could ask in the melon line. Of all the sweet heart melons we believe that Halbert's is the best. Like Kleckley's Srreet it is a home grower's melon; thin rind, deep green skin, deep red flesh; a favorite wherever known. Again we want to say that our seed is absolutely true to name, type in every respect. You can't go wrong buying this seed.

New Wonder. This is the fine, deep green, red fleshed melon grown along the Salt Fork so successfully last year. Absolutely purè seed direct from Virginia. 15c oz, \$1.00 $\mathbf{1 b}$.

Early Fordhook. This melon is extensively grown in the north. We are not well acquainted with it. But list it this year to give it a trial under our weather and marketing conditions. It comes highly recommended. It is very early and is recommended highly for shipping. Medium large, half hound, redmeated. Try some of this seed. 


\section{Watermelons (Continued)}

Sweetheart. Oval, light green, mottled. A very good type of melon for home consumption. Good shipper.

Peerless. This melon is also known as the "Ice Cream" watermelon. In good demand. Those who have grown it always call again for "Ice Cream" melon seed. It is an early melon, oblong, rind thin, light green mottled and veined with a deeper green. Flesh bright red and very sweet.

Imp. Kolb's Gem. Large size, the old stanilby of our grandfathers. Nearly round, rind dark green, striped, fair quality.

New Winter. This melon, contrary to the advertising of some seed houses who state that it originated in Russia, is a product of our own South, where it has been grown for many years. Its keeping qualities are remarkable, many instances being on record of melons being eaten in the spring. Try this melon. Per ounce 20c.

Yellow Meated. This melon is rapidly coming to the front in the markets. Its flesh is a bright yellow, dark seed, very juicy and sweet. Ounce 20c

Red Seeded Citron. This is the preserving melon. To those who have never preserved citron let us say that they have missed a treat.

\section{MUSTARD}

\section{Ounce 10c; $1 / 4$ Ib 30c; 1 lb $\$ 1.00$}

Mustard is grown for both seed and "greens" purposes. It can be planted, either sown broadcast or in rows, very early in the spring.
Southern Giant Curled. The favorite in the south.

Chinese. The large leaves are ready for use six weeks after sowing. Either variety does well here.

\section{OKRA}

Ounce 10c; $1 / 4$ it $30 \mathrm{c} ; 1$ it $\$ 1.00$

This vegetable is not nearly so well known as it should be. Used in soups or fried it is a wonderful addition to the garden vegetables. It is very easily grown, a few stalks providing until frost sufficient pods to care for the needs of the average familv. 'The rods should be used when quite young. Yarboiled in a solution of weak salt water then fried in butter, well seasoned, okra is a de- licious dish. Stliced and used in meat or vegetable soups they add materially to food value and palatibility. Don't neglect a few hills this spring. Plant at corn planting time.

Dwarf Green Pod. Grows low but stocky; very productive.

White Velvet. Produces pods larger than any other.

\section{Cow Peas and Soy Beans}

Few farmers seem to realize they are passing up a great opportunity by not raising Cow Peas and Soy Beans for market. There is a great and increasing demand for these products for various purposes-besides the raising of them for soil improvement. We sold to one person last year peas sufficient to plant two hundred acres of peas. Through failure to find proper method of getting the peas picked he lost several thousand dollars. Our suggestion is this: Plant the peas, they always do well; pay $\$ 1.00$ per hundred pounds for picking, as they do in the pea growing regions. Have them threshed. They will command a splendid price. They produce more than wheat to the acre normally, thereby giving a double profit-the bettering of the soil and a real return in cash. From eight to fifteen pounds to the acre is sufficient for sowing of either Cow Peas or Soy Beans. Give them a chance. They will make good.

\section{We Have the Seed. Prices in Large Quantities on Application.}




\section{ONION SETS}

Yellow and Red Sets 15c qt. 2 qts. 25c, subject to market changes. White Sets $20 \mathrm{c}$ qt. 2 qts. $35 \mathrm{c}$

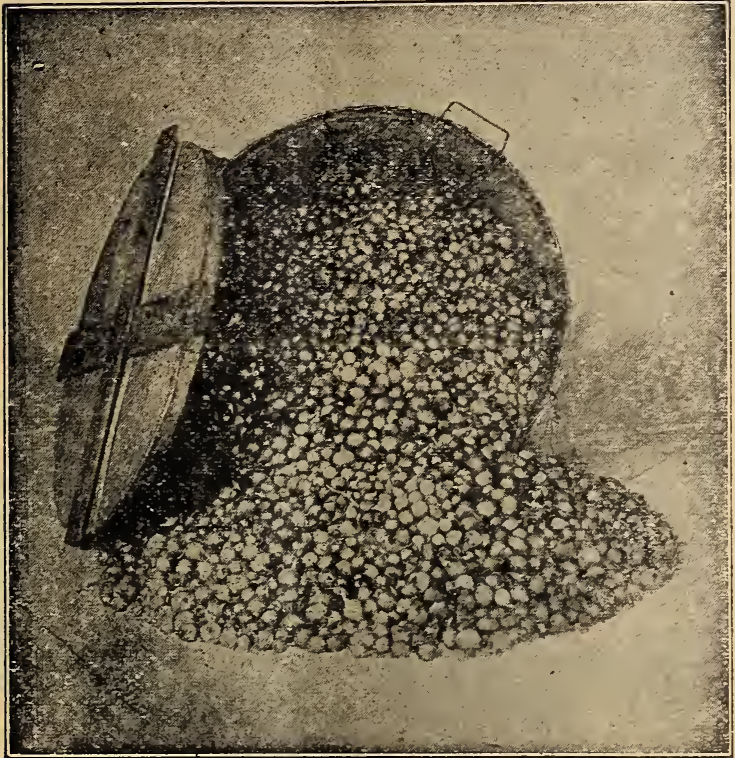

OUR WHITE ONION SETS

Theie is a great difference in Dnion Sets. It can be noticed by simply observing the external appearance, then later the mature onion shows a marked difference. Leonard's sets and the common sets of commerce. Our sets are grown in the great Chicago district whihe produces the best sets grown in the United States. Our sets show from their external appearance that they have been well cared for, properly grown, true to variety, and that great care has been taken to keep the seed from which they are grown at a high standard. Our sets are all graded over one-inch screen, which gives a very large preponderance to the quart of small sets, which will produce better onions than the larger sets; and they are clean Many of our customers buy them by the bushel and pay us more for them than is asked for the common sets. TVe have several customers who buy from $\mathbf{2 5}$ to $\mathbf{5 0}$ bushels each year and insist that 110 other sets, though cheaper, be sold them.

Onion sets can be planted here in February, as the light freezes we can reasonably expect from then to spring has no effect on the growing plant. Don't fail to get these best sets early; they will cost no more than cheap, ungraded stock.

Yellow. Grown from seed of Danvers of Strassburg.

Red. Grown from Red Weatherfield seed and will produce remarkable onions earlier than any other variety.

White. Grown from White Portugal seed. White sets produce the finest early green onions. No garden is complete without them. All these varieties produce high yields of ma- ture onious, much better in quality than the colinizon sets.

White Multipliers or Shallots. This is one of the finest onions for early green onions. Very productive here and in great demand. $20 \mathrm{c}$ per quart.

Yellow Shallot or Multiplier. Same as white except in color. 20c quart or pound.

Prices on onion sets subject to market conditions.

\section{ONION SEED}

Many people plant onion seed for their main crop here and are very successful with them The great factor in raising onions from seed is early planting and GOOD SEED. The life of the onion seed is short. Therefore it is to your interest to buy only seed which we are certain will grow. The other factor is early planting. Onion seed should be planted in February in our territory and not later than March 1st. Don't forget this and don't neglect it.

Ounce 25c; $1 / 4$ to $75 \mathrm{c} ; 1$ th $\$ 2.50$

Early Danvers. A good variety but not as early as Yellow Danvers.

Yellow Globe Danvers. This onion is of fine size. A heavy cropper.

Prizetaker. Grows to an immense size. Very mild, yellow skin, fine keeper. To get the best results plant seed in hot beds, when large enough, transplant.
Large Red Weatherfield. We have a very fine and select strain of this onion. Color a deep red, white flesh. Yields enormously and fine keeper. Plant more of these.

White Portugal. This is the best sort to sow for early green onions and for pickling. When sown for either it makes a small round, solid bulb. 


\section{Onion Seed (Continued)}

Bermuda Red. A very pale red onion, which should not be sowed.so early as the other varieties as it fails to stand the cold weather of March. 40c per oz.

White Bermuda. The name is misleading, as it is a pale yellow skinned onion. Same as Red Bermuda. 40c per oz.

Crystal White Wax. A large, beautiful, silvery white skin. Flat, very mild. Same planting instruction as for other Bermudas. 40e per ounce.

\section{Bermuda Onion Plants}

A great trade has sprung up during the past few years in Bermuda Onion Plants for spring planting. They are rery reasonable in price, there is no reason why several hundred plants slould not be put in every garlen. If the weather should prove warm during March and April they would repay planting many fold. 15e per 100 ; 75e for $500 ; \$ 1.50$ for 1,000 . P.stage or express prepaid direct to you. Order early, stating time wanted for delivery.

\section{PARSNIPS}

One ounce $15 \mathrm{c} ; 1 / 4$ it $40 \mathrm{c} ; 1$ ib $\$ 1.50$

Plant garsnip as early as soil can be worked in the spring. Thin the plants to three inches arat in the row. Right here is why so many people fail to raise parsnips here. They will not thin them properly. The parsnip requires a long growing period, until fall in fact, and can be left in the ground all winter. F'reezing improves them wonderfully. They can be used for stock and poultry feeding.

Hollow Crown. Roots long, smootli, tender, sugary and of most excellent flavor.
Guernsey. Roots white, very tender, with smootl, clean skin. These two varieties are the best for our growing.

\section{PARSLEY}

Used for garnishing and seasoning.

Champion Moss Curled. A fine curled variety. $15 \mathrm{c}$ per ounce.

\section{FANCY GOLD FISH}

We carry an exceptionally fine selection of Japanese Gold Fish, Jars and Tanks.

Common Fish 15c, 25c and 50c Each

To see these beautiful fish is to want them.

Japanese Fan Tails, each.................75c

Japanese Comets, each.........................75c

Japanese Fringe Tails, each $.85 \mathrm{c}$

Japanese Telescopes, each $75 \mathrm{c}$

Farmers: Plant Kanota Oats, Sweet Clover, Alfalfa, it will pay you to use our seeds. Special prices on large quantities. Write us.

\section{TREEMAN \& MUNGER}

PERRY, OKLAHOMA 


\section{PEAS}

\section{All Peas 25c per pound; 2 pounds 45e}

Peas to be most successfully grown in Oklahoma should be planted very early. Frost does not hurt them to any great extent. Plant early, except the wrinkled sorts which should not be planted until the ground is warm and dry. Keep the vines picked clean of maturing peas. This method will materially lengthen the bearing season. Our varieties, while small in number, we know liave been giving satisfaction to all growers here. While it is more than possible we have overlooked some good ones, yet we feel sure you will find that the varieties we have are best for our weather conditions.

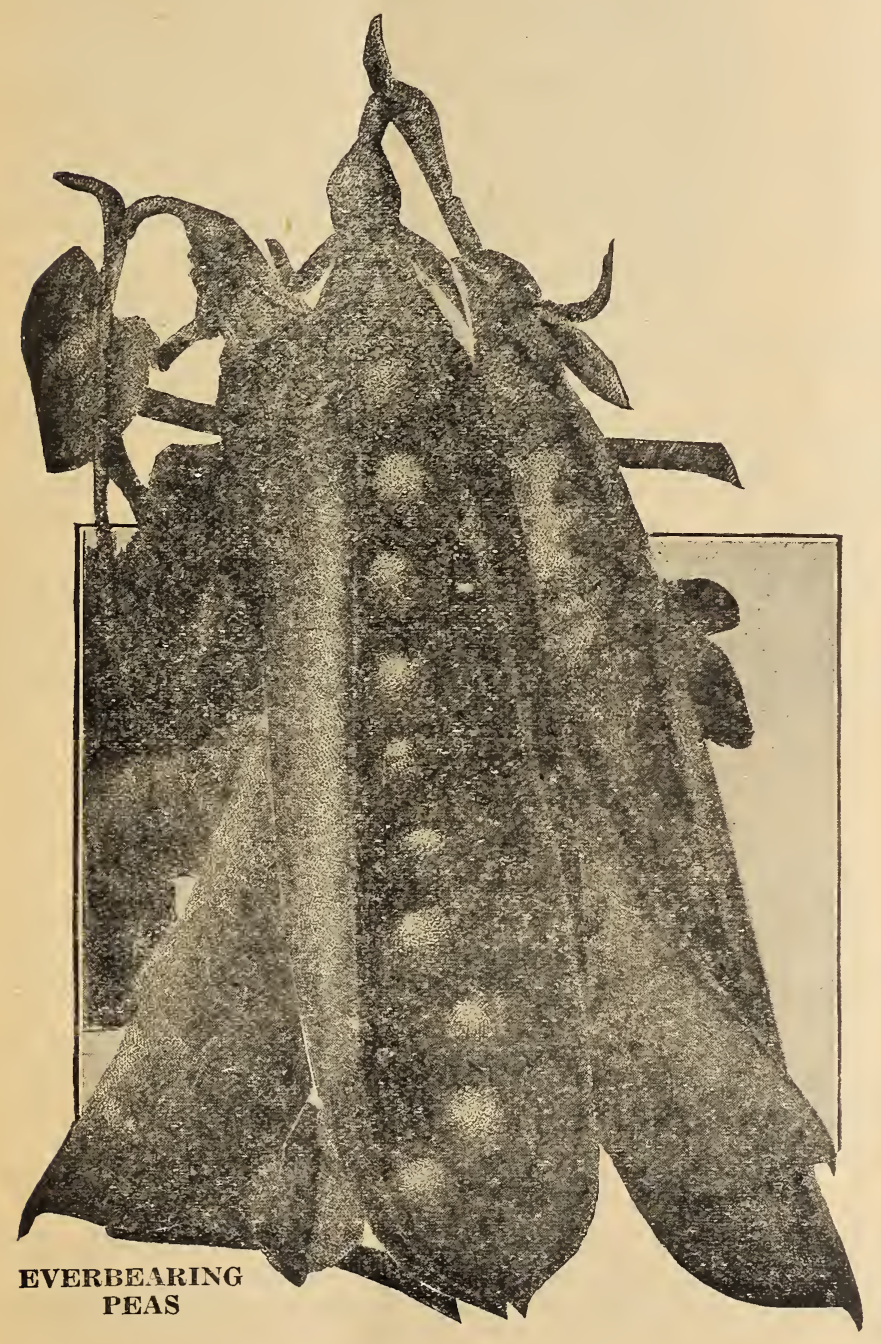

Alaska. Possibly the most widely known of the peas. Smooth seed, rery early, and when carefully grown, uniform in ripening. Is ready for picking 50 days from planting. Seed round, blue, slightly pitted.

First and Best. Early, productive and hardy, 2 to 3 feet in height, requires no sticking. Seed round, rather small and white in color.

Little Marvel. A sudwarf pea, very sweet of dark green color. 15 inches high.

Wh it e Marrowfat. Height 45 to 50 inches. Very hardy, strong, tremendous bearer. Seeds large, smooth and white.

American $\quad W$ onder. Nine to twelve inches in height; very desirable for home garden; fit for picking 55 days from planting.

Drw a r f Telephone. Vines 18 to 20 inches high. Ready for picking 60 to 65 days from planting.

Premium Gem. 18 to 24 inches high. Seed green, wrinkled, medium in size. Very desirablè sort.

Blue Bantam. An early perior dwarf sweet pea and productive.
McLean's Little Gem. Strong and vigorous; 18 to 24 inches high; ready to pick 59 or 61 days after planting. One of the very best sorts.
Laxtonian. Largest podded of the dwart peas. Vines vigorous and productive; the mast desirable of all the dwarf peas. Fifteen to eighteen inches high; pods four inches long. 


\title{
PEAS (Continued)
}

Everbearing. Vigorous and branching in habit. 30 to 36 inches high. Requires no sticking. Fit to pick 70 days from plantiu. One of the very best late varietiese.

Champion of England. 42 to 50 inches high. 68 to 73 days from planting. Perhaps the very best of the tall growing wrinkled peas for use here. Our customers have been well pleased with it.

Melting Sugar, Edible Pods. This pea deserves more attention than has been given it. The pods are edible and it produces in great abundance. Fit for use 80 days from planting. This quality of the pea in no way affects its use as other varieties are used. By all means try this pea this year.

\section{PUMPKINS}

All Pumpkins and Squashes 10c per ounce; $1 / 4$ it $40 \mathrm{c} ; 1$ it $\$ 1.50$

With normal weather pumpkins can be grown here to great advantage. The cost of planting is so small compared to the value of the crop, if it hits, that everyone should put in a few hills of several varieties each year. With our long growing period in the fall pumpkins and squashes can be planted later here than in the north. Don't neglect to plant some of each this summer.

Cheese or Kentucky Field. One of the largest varieties.Used extensively for stock and poultry feeding.

Mammoth Potiron: Grows to an immense size, often weighing 200 pounds. This is the variety which has taken prizes at the Noble County Free Fair for several years.

Cushaw or Crookneck. A favorite of ex. cellent quality. Splendid for home cooking and pie making.

Tennessee Sweet Potato. Hardy, produc tive, sweet. The very best large pumpkin for home use.
Sugar or Pie. One of the small varieties used extensively for cooking.

Summer Crookneck Squash. Standard summer squash about a foot long.

Mammoth White Bush Squash. The improvement over the small white bush is very marked in size.

Early White Bush Squash. Is earlier than any other variety, dwarf and very productive.

Leonard's White Hubbard Squash. One of the best strains of warty Hubbards. Dark olive green in color. It will keep over winter. The very best strain of seed.

\section{SQUASH}

\author{
10c per oz., $1 / 4$ It 40 c; 1 It $\$ 1.50$
}

The Hubbard. More popular with home color. gardeners than any other variety.

Pike's Peak. Skin smooth, dark, olive green in color. Matures with Hubbard. Splendid for cooking.

Mammoth Chili. Grown for exhibition and stock feeding. Very large, rich orange

Fordhook. Fruits oblong, 8 to 10 inches long, smooth, thin, yellow skin; flesh very thick.

Delicious. This is among the best winter varieties. Green shaded skin; flesh dark orange. Splendid for eating purposes.

\section{PEPPER PLANTS}

Just a few short years ago green peppers were looked upon as an oddity in the garden for table consumption. Today they take their place with the foremost of the garden fruits for the home table. Eaten ice cold raw, with a dash of salt, used in soups, boiled, fried, and in the making of egg omelet they add a spice whihe should be greatly appreciated to your vegetable menu.

Pepper plants ready to put out, from $2 \frac{1}{2}$ inch pots at planting time in the following varieties: Ruby King, Bull Nose, Chinese Giant. 10c each, $\$ 1.00$ per dozen. Write for prices on large quantitiees. We will have any number you may require. Special rates made to market gardeners. 


\section{PEPPER SEED}

All Pepper Seed, except where noted, 35c per ounce

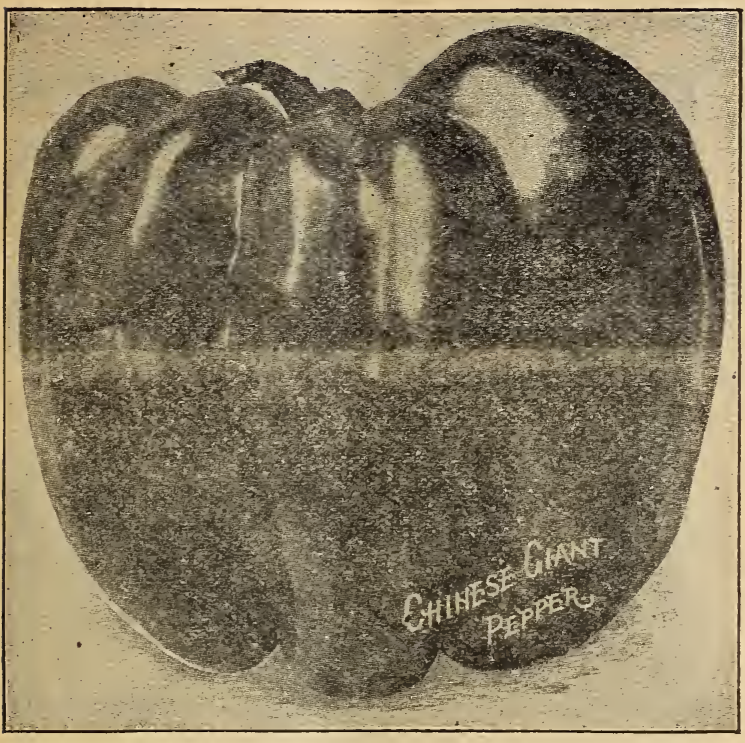

Large Bell or Bull Nose. A very large sort or inverted bell shape, suitable for filling or for mixed pickle.

Ruby King. An improved American variety. Very large and attractive.

Ruby Giant. Larger, smoother, finer grained and sweeter than Ruby King.

Rerl Chili. Used in the manufacture of chili sauce.

Pimento. A very thick fleshed, smooth, mild, crimsoll variety much used in salads. 30c per ounce.

Long Red Cayenne. Long, slim. pointed pod, when ripe of a bright red color. Very strong. Grow your own peppers this year.

Chinese Giant. Without doubt olle of the finest and largest Mango peppers introduced. 50c per ounce.

\section{STRONG POTTED PEPPER PLANTS}

These plants are potted in 2 and 3 inch pots, many blooming ready to go to bearing soon after thoroughly establishing themselves.

Sweet peppers are rapidly growing in favor with the home gardener; there is a ready sale for them at grocery stores at a good price; they are splendid for all kinds of home cooking.

We grow the following varieties:

Chinese Giant, Ruby King, Giant and Cayenne.

2-inch Pots, 10c each, $\$ 1.00$ per dozen.

3-inch Pots, $15 \mathrm{c}$ each, $\$ 1.50$ per dozen.

For transplanted plants see price list on order page. Special attractive prices to large growers. All plants delivered direct to you free.

\section{MAMMOTH RHUBARB PLANTS}

Another successful year, 1925, for our splendid Rhubarb Roots. We do not sell divided roots. You buy the entire root. They make good every year. John Peterson of Orlando, Oklahoma, bought several hundred roots last year. He made good money from them the first year, besides having his stock ready for use again this season. He states that he will buj 500 this year; and that rhubarb grown from our Mammoth Roots is ready for the market by the time southern plants are ready.

For the home garden there is nothing finer nor more lasting. Not divided, small chunks of roots but the entire Mammoth Root. which should be planted in soil deeply spaded, well fertilized with well rotted stable manure, so that the bud of the root is just ready to peep through the soil. Planting should be made in March or the first two weeks in April. DON'T FAIL TO USE THE STALKS THE FIRST YEAR. The plants will more than pay for themselves in this way, assuring plenty of fine rhubarb for the home.

Mammoth Rhubarb Roots, \$1.50 per dozen: \$9.00 per 100, f. o. b. Perry, Okla. Postage or express extra at cost.

Victoria. The large stalk variety. Not what is commonly referred to as the wine plant. Seed. 20c per ounce. 


\section{RADISH}

\section{All Radish 15c per ounce; 2 ounces 25c; $1 / 4$ 16 50c: 1 16 $\$ 1.25$}

We have endeavored to make our radish selections those which give the most satisfaction from a gardener's standpoint and for home gardens.

White Icicle. An early, long, white radish.

Scarlet Turnip, White Tipped. On of the best turnip radishes and a great favorites. Solors deep scarlet with white tip.

French Breakfast. Olive shaped: scarlet with white tip, crisp and tender. A favorite with most people. Very early.

Early Long Searlet Short Top About six inches long, bright scarlet smooth, crisp and tender.

Garly Scarlet Globe. Very ears, sild, crisp, tender. Will stand the heat without becoming pithy.

wrrmson Giant Foreing. Grows to an unusually large size, always tender, crisp and of mild flavor.

Early Scarlet Turnip. The standard early turnip radish.

Chartier. A long-root variety. Bright red at top changing to white at tip. A splendid variety.

White Strassbuíg. Many people like the Strassburg better than the Icicle. Grows with great rapidity.

Summer Turnip White. White, very erisp and mild. Large.

Sparkler White Tip. This is a new radish coning to us very highly recommended. Much on the same order as Turnip White Tip but more crisp and larger. Try it this spring.

Winter Varieties. The winter radish can be sown at the same time as turnips, treated

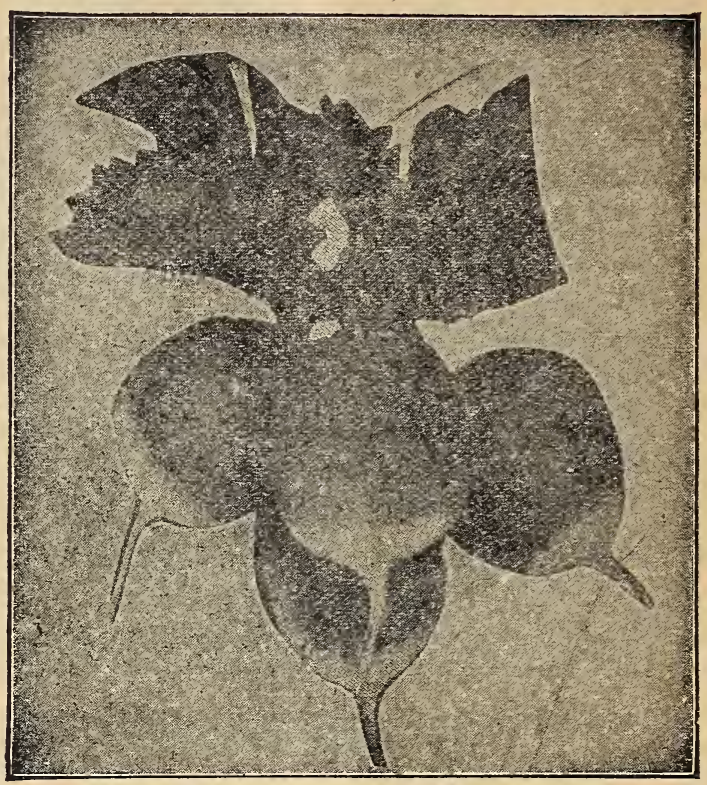

SPARKLER WHITE TIP RADISH

in the same way. They grow large and are very crisp and sweet. Plant some when you plant turnips this fall.

Rose China Scarlet. Flesh is firm, crisp tenter and pungent.

Long Black Spanish. One of the lateset as well as the hardiest of the radishes. An exrellent sort for winter use.

\section{SPINACH}

\section{0c per ounce}

Sow as early in the spring as the soil can be worked. Spinach is used for "greens" and from the standpoint of recent investigations is high in vitamines so necessary to life and health. Spinach is one of the few vegetables recommended by every dietitian in digestive disorders. Easily grown, it should occupy a space in every home garden.

Savory Leaved Bloomsdale. The earliest variety and one which should be planted both spring and fall. It grows quickly to edible size but soon runs to seed.

Long Standing. The leaves are smooth and very dark green, continuing in condition for a long period.

Victoria. An excellent sort which becomes fit for use very early and remains in condition for some time.

\section{SALSIFY}

Manmoth Sandwich Island. This is perhaps the best Salsify or vegetable oyster grown here. 15e per ounce.

Sorrel, Large Leaved French. The standard variety. 20c per ounce. 


\section{TOMATO}

Except where noted 30c per oz., $1 / 4$ oz. 10c.

Our seed is grown by one of the most reliable growers in the United

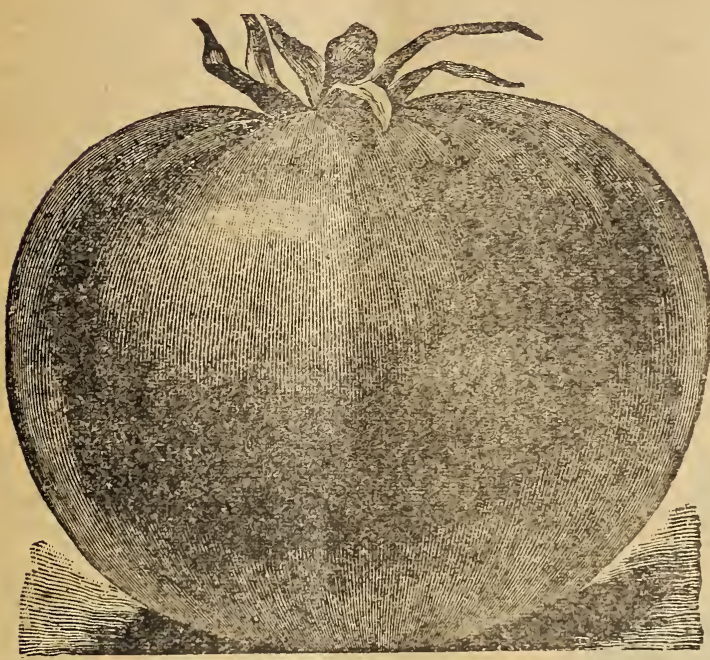

NEW STONE TOMATO States, in Michigan, and greatest care is exercised throughout the growing and fruiting season to see that no rogues are left in the field to ruin by pollination the distinct varieties. You caunot get better tomato seed, nor truer to name seed than we offer you.

Norton's Biight Resistant. Will endure more blight and produce fruit than any other sort yet found. A highly specialized Earliana in type, very productive.

Eariana. Deep scarlet fruit, best known of early varieties. Always (iependable.

Chalk's Early Jewel. This is one of the best early fruiting varieties.

John Baer. An early red tomato ver'y productive.

Bonny Best. A favorite of many people. Red.

June Pink. The best, to our way of thinking, pink tomato on the market. Very smooth, does not crack at stem, medium to large.

Acme. The well known popular pink tomato.

Livingston's Beauty. Large, solid, smooth Purplish pink. One of the very best.

Matchless. The best large-fruited, bright red tomato. Later than some other varieties but continues in fruit from early in the summer until frost.

New Stone. Vines vigorous and productive. Bright red fruit. The favorite of many.

Livingston's Globe. A beautiful globeshape, glossy rose, tinged purple. We think it one of the very best.

McGee. Gardeners' favorite. One of the early sorts.

Red Kock. We had so many calls for this tomato that we stocked it last year. Very solid, smooth, heavy producer under any weather conditions.

Dwarf Stone. A true tree tomato. Fruit similar to New Stone.

Ponderosa. A purplish pink tomato of largest size. It does remarkably well here provided the vines are kept free of the ground. 'This can be done by setting posts at the end of each row, stringing wires and tying the plants with cotton strips to the wire; or by frames built around each plant. It will surprise you how all the tomato varieties will respond to this treatment. $50 \mathrm{c}$ oz., $1 / 4 \mathrm{oz}$. $15 \mathrm{c}$.

Yellow Pear. Pear-shaped. A splendid variety for preserves. 50c oz., 1/4 oz. 15c.

Red Pear. This is the leading preserving tomato. Also used to make tomato figs. This is done by putting the tomatoes away in pure sugar. It will repay anyone to try this. 50c an ounce, $1 / 4 \mathrm{oz} .15 \mathrm{c}$.

We cannot build a successful seed trade with cheap seed -we are not trying to do this-but we are trying to give the best we can buy. Give our seed a trial this spring, though it be only a small order, it will receive the same careful attention as large orders. 


\section{Wonderful Potted Tomato Plants} garden.

Ready to produce tomatoes weeks ahead of outdoor plants. Buy a dozen for your early

Plants from 3 inch pots, blooming $15 \mathrm{c}$ each; plants from 2 inch pots $5 \mathrm{c}$ each

The tomato requires 100 days to mature from time of planting seed. The usual method of planting is in hot beds or boxes which can be taken care of in the house. Anyone can do the latter. For those whowant early plants, however, we offer the very best plan. One of the surest methods to have early tomatoes is to buy the plants which were transplanted in March to single pots, blooming at time of putting out. While they cost more, yet the time gained in fruiting more than balances the extra cost. We raise the following varieties:

Earliana, Chalk's Early Jewel, June Pink, Acme, Matchless, New Stone, Ponderosa. All these are the very best known. Don't fail to buy a few plants, potted and blooming. Transplanted plants at market prices. $10040 \mathrm{c} ; 200 \mathrm{75c} ; 300 \$ 1.00 ; 500 \$ 1.35 ; 1,000 \$ 2.25$. Postage or express prepaid direct to you.

\section{TURNIP}

Except where noted, 10c per ounce; 75c per pound

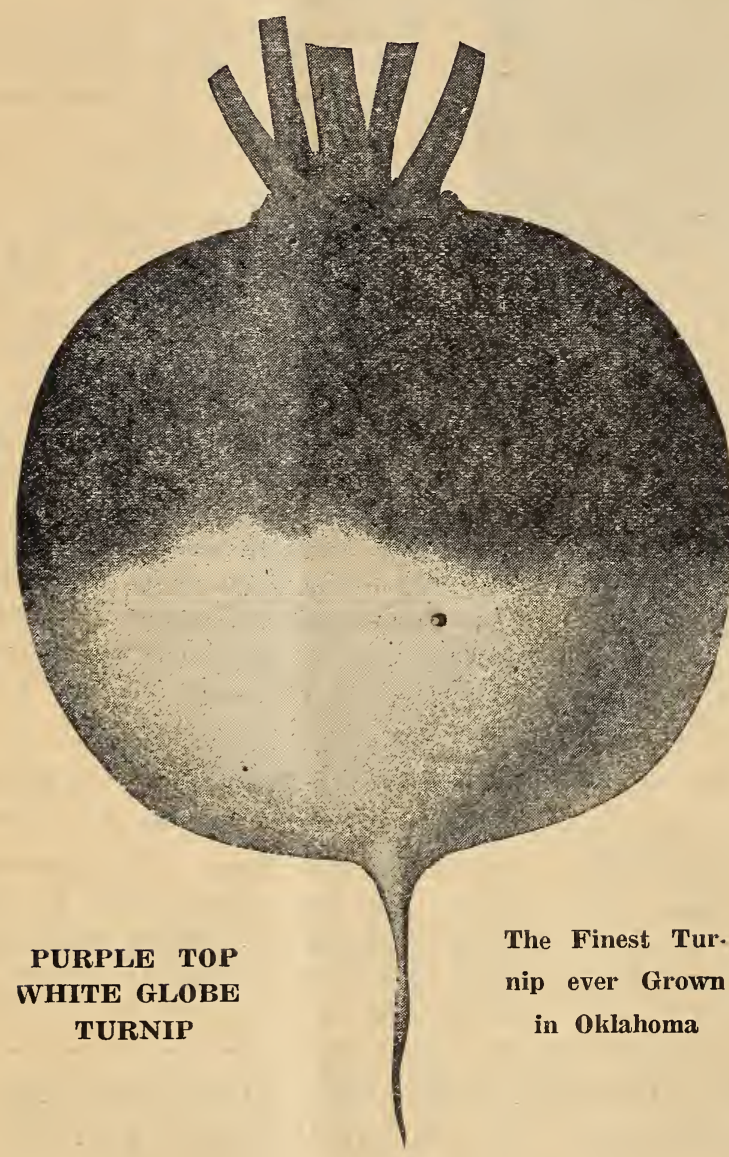

We are proud of the record our turnip seed has made during the past three years. While necessarily there are some who were unfortunate in their planting time, yet the samples which have been brought to our store proves to us that we are giving the very best service on turnip seed. ExSheriff Hoover, of Perry, is, we believe, the champion turnip grower of Oklahoma. Year before last he brought us Purple Top White Globe turnips which weighed better than 7 pounds. Sweet, tender and crisp without the slightest woodiness. He repeated again last year with Purple Top Strap Leaved, which were wonderful. Everyone should grow these turnips. While it is impossible to always get a stand, due to weather conditions in the fall, yet keeping at it will invariably bring results. Of course we are not responsible for the weather and we do know that some seed sowed this fall, early, failed to produce, but in no instance has it proven that it was the fault of the seed. Turnips are valuable for stock feeding, and are proving particularly valuable for poultry feeding. Do not neglect to plant this spring and again in the fall.

Extra Early White Milan. We have here the best and most rapidly growing spring turnip on the market. Pure white. 15c per oz.; 1/4 It 50c; 1 Ib $\$ 1.00$.

Purple Top Strap Leaved. Rapid grower and mild flavor. The most popular variety for early use, either table or stock. Does best however, when planted in the fall.

Early Snowball. Another good turnip for early spring and summer use.

Purple Top White Globe. The best turnip for Oklahoma that we have ever seen.
Don't fail to plant it this fall.

Cow Horn. Pure white, carrot-like in form growing partially out of the ground; long, irregular, very sweet. 


\section{RUTABAGAS}

Treated the same as the turnip, but differently flavored. Really better to plant in rows, about one month earlier in the fall than turnip and then thinned.

Improved American. The best of the yel-

Skirving's Purple Top. A very heavy field low fleshed varieties. cropper. 15c per oz., $1 / 4$ it 50c; 1 th $\$ 1.50$.

\section{Flower Seeds}

There are so many people who think because we have long, dry, hot summers, that it is useless to think of planting flower seeds. After watching the various seeds planted, their development from tiny shoots, through the growing period to blossoming time, their powers of resistance to conditions over which we have no control, and then sending forth bloom which defy weather and hot winds, we have come to the conclusion that it is very much worth while to plant certain flower seeds for the beauty which they give us. There are others which we are listing, which, of course, eannot make it through, but with reasonable care most of them will. There are also those which withstand every condition. Those are the flowers which we shall recommend for planting in the home garden and about the yard.

The seeds cost so little compared to the joy they bring into the home life of every family that everyone should have at least a few well known flowers. Preparation and proper fertilization of the soil plars a great part in the life and resistance of the plant. Therefore before planting be certain that the soil has been spaded deeply, well rotted manure worked into it, firmed down as the farmer does his field for alfalfa culture and the seeds, many of which are very tiny, not covered deep. Most flower seeds are very small; and most are planted too deep. Remember to barely put the small seds under the soil, firming it over them. We shall try to indicate to what depth the various seeds should be covered. If the planter will remember that seeds which fall from the parent in the fall comes up in the spring, and that merely the weight of the seed and Nature's own covering by dust is usually sufficient, we are certain you will be more successful in getting a stand.

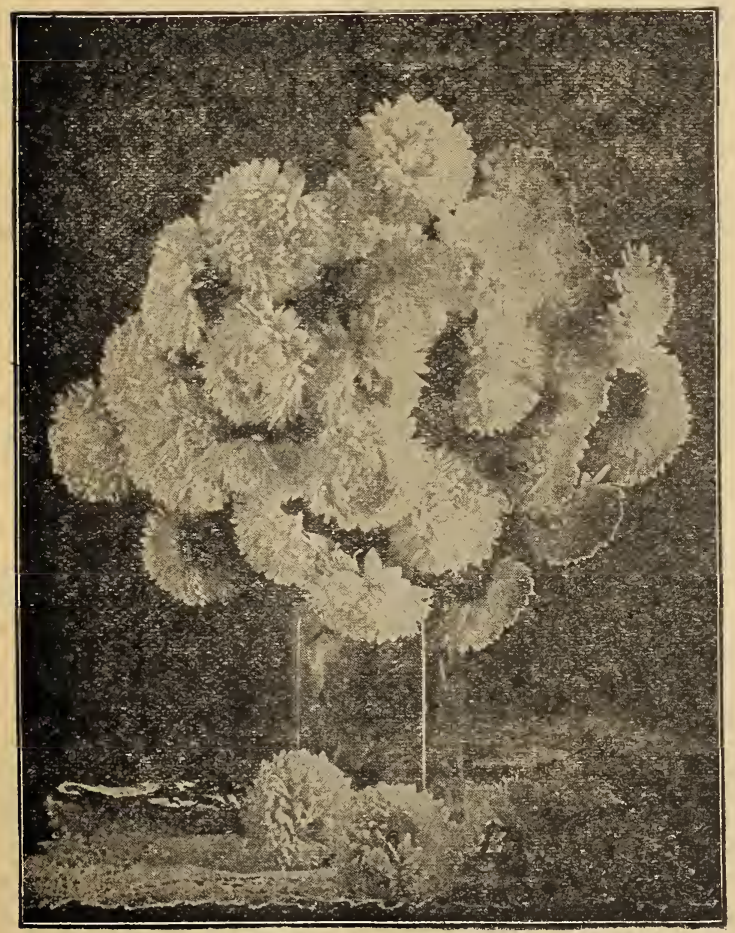

\section{ASTERS}

Among the most beautiful and easiest raised of all summer plants.

Try a bed composed of our mixed colors this season.

Plants, 75c per dozen. Special prices on large quantities.

Periwinkie (Vinca) Red, white, white and pink. \$1.00 per dozen.

Salvia. Splendid red. $\$ 1.00$ per dozen.

Sanctonia. Splendid plants $\mathbf{\$ 1 . 0 0}$ per dozen 


\section{FLOWER SEEDS (Continued)}

Sweet Alyssum. For beds, edgings, etc. Seeds small. Should be planted barely under the soil. Pht. 10c.

Balsams. Easily grown, many colors, will care for their own seeding after once started. Seeds planted one-half inch deep. Pkt. 10c.

Cosmos. Easily grown, requires only ordinary care. Plant $1 / 2$ inch. Single, mixed. Pkt. 10c; double mixed,Pkt. 25c.

Cypress Vine. Most beautiful climber with very delicate fern-like foliage and numerous bell-like flowers, red and white. Pkt. 10c.

Pansies. The very finest mixture obtainable of large blooming pansy. Plant early in the spring, or in fall, give it half a chance and it will produce magnificently for -you. Pkt. 10c.

Columbine. Popular perennial, once plant ed always there. Really the seed should be planted in the fall. However spring planting may survive. Pht. 10c.

Asters-Semi-Hardy. A most beautiful late summer plant in many colors. Our Aster: are direct to us from California and are the best that we can buy. Mixed colors. Pht. 25c.

Carnation. Contrary to popular belief Carnations can be grown out doors. Again shallow seeding, plenty of water during the germination period, then ordinary care through the summer. Mixed colors. Pkt. 15c.

Dahlia. Sow the seeds early in pots or boxes, and transplant to goud soil. Will bloom the first season. Pkt. 10c.

Perennial Larkspur. If sown earìy will bloom first year from seed. A desirable addition to any garden. Most recent introduction. Pkt. 25c.

Pinks. Without a superior among flowers. Mixed colors. Plant $1 / 8$ inch. Pkt. 10c.

Grourds. Mixed many kinds. For use wherever they have an opportunity to climb. The children like them. Pkt. 10c.

Hollyhocks. Seeds should be sown in fall for next year's flowering. Can be planted this spring. Mixed colors. Pkt. 10c.

Moonflower. Beautiful and popular white climbing plant. Pkt. 10c.

Marigold, African. Best adapted to growth here. Rich orange in color. Grows anywhere. Pkt. 10c.

Marvel of Peru-Four O'clock. Grow any. where. Very fragrant. Pkt. 10c.

Morning Glory. Imp. Japanese. Very large flowers, blossoming in fall. Pkt. 10c.

Nasturtium. Tall mixed colors. This plant needs no introduction. Grows in any garden and under any condition. 15c an ounce; 2 ounces 25c.
Nasturtium. Dwarf, mixed colors. 15c an ounce; 2 ounces $25 c$.

Snap Dragon (Antirrhinum). Mixed many colors. One of the most beautiful and easiest raised plants. Don't fail to plant thern. They will live here through the years. Small seed. $1 / 8$ inch. Pikt. 15c.

Petunia. We have the best and newest varieties of petunias. Don't fail to get them. Plant shallow. After that they will take care of themselves.

Phlox. Drummondi and Decussata. Two splendid varieties. Don't fail to get them. Plant shallow, keep well watered at the roots, and not the entire plant. Pkt. 10c.

Poppies. California, Carnation flowered, Shirley-the very best varieties. Plant shallow and early. Each, Pkt. 10c.

Castor Oil Plant. Enormous growth in one season. Best thing known to keep moles out of garden. Pkt. 10c.

stociss. Little known here but the delight of many people. Seed small, plant shaliow and eariy, transplant, give them o chance Pint. 10c. Mixed colors.

Portulaca-Moss. The very best, mixed colors and double. The surest early spring Howering. Simply scatter the seed, press with hand. Never needs replanting. Pkt. 10c.

Summer Cypress-Kochia. Used for bedding and borders. Grows very rank cedar-like growth turns to fiery red when frost strikes it. Can be used to hide unsightly places or for highly decorative purposes. Grows any place. Once started always with you. Try it. Pkt. 10c.

Sweet William. Our seed is the best mixture of this old-fashioned lovable plant we can find. Grows any place with ordinary cultivation. Both single and double. Pkt. $15 c$.

in many instances will live over winter. Unce planted will take care of itself from year to year. Don't fail to get our splendid mixture Pkt. 15c.

Verbena. Low growth plants for bedding. parking and borders. Always in blossom and

Zenia. Absolutely the finest of fall dlowers for this country. Will withstand any amount of drought. Our mixture is the best that we can buy, of the many new types of this flower. You will be surprised at the wealth and beauty of blossoms, both on the plant and used for cut flowers. Don't fail to plant this year. Plt. 15c. 


\section{SWEET PEAS}

To merely say Sweet Peas brings pictures to every mind of beauty and fragrance. Many people here think that Sweet Peas are hard to grow. It must be because they have never tried them. Plant deep-five inches at least-in February. Then gradually fill the ditch as the plants grow. This firmly sets the plants and they will yield beautifully.

Eckford's Mixed. A good mixed variety Yields a wealth of blossom and very fragrant. Ounce 15c.

Spencer's Hybrids. The finest sweet peas in existence. Just as easily raised as the cheaper variety.

Our mixture is composed of the finest named varieties, many of them new colors. Try them. 30c ox.

Sweet Peas should be planted from February 1st to April 1st to secure finest blooms.

\section{MA KE THE COUNTRY HOMES BEAUTIFUL}

Read ove: car" entire list of wonderful CANNAS, make your selection and order now. CANNAS

There is nn surer bloomino nor more luxuriant flowering plant grown here than the Canna. We have seen many growing in the gardens of the country homes, as well as of town residenres. during the rast three years, giving a wealth of blossoms from early June until frost. Plant tre roots about 4 inches deen in well-prepared soil in April, give good cultivation and watch them pay for it. One can have the plants for many years by taking the bulbs up in the late fall or by covering with manure or straw after frost strikes them. Be sure to try at least. a dozen this spring.

KING HUMBERT. Bronze foilnge, scarlet. $75 \mathrm{c}$ per dozen.

THE PRESIDENT. Green foliage, flaming scarlet. The pride of the garden. \$1.25 per dozen.

FIKE BIRD. Green foliage, the best deep scarlet. \$1.00 per dozen.

ROSEA GIGANTEA. Green foliage, rose pink, large bloom; very handsome. \$1.75 per dozen.

M. M. WALLACE: Namerl after the daughter of Secretary of Agriculture Wallace. Comes to us righly recommended from our grower in Virginia as one of the finest ever producerl. Light rose pink and very tree bloomer. While high in price yet it is certainly worth while to the lover of beautiful Howers to get a good start of a variety little known. Some of our most beautiful flowers have been disceminater in just this way.

25e each. \$2.50 per dozen. A wonderful American Beauty color.

AMERTCAN BEAUTY: A rich American Bnaty rose in color, stands hot weather remarkahly well, very prolific in blooming. 25c eack. \$2.59 per dozen.

APRICOT. Four feet in height: a rich aprient. very distinct and unique. One that can stand the drought and heat without losins color. grows anywhere and very strong. Highl r recommended. \$1.50 per dozen.

KING MIDAS. Four feet, the very best yellow erer produced, new. We have only a very limited number of this Canna as the grower would allow us but few. Color orange yellow, green foilage. 40c each $\$ 4.00$ per dozen.

VELLOW KING HUMBERT. One of the hest and most showy of the yellow Cannas. Blossoms splotehed red and yellow. Distinct. $\$ 1.25$ per dozen.

All Camnas are quoted delivered direct to yeu. We shall be pleased to quote special prices on large quantities for heavy plantings. Don't hesitate to write us your requirements. They will receive our immerliate attention ans close prices.

\section{DAHLIAS}

Dahlia Plants from 3 inch Pots 20e each, \$2.00 ner dozen; Dahlia Bulbs 20e each $\$ 2.25$ dozen

A very few years ago it was thought that Dahlias could not be grown here. Dahlias have proved conclusively that they will endure every kind of weather, bloom in spring, and again in the fall until frost kills them. Deep soil preparation, well fertilized with rotted manure or bone meal will prove to the most doubtful that these magnificent flowers can be grown here. They come in a multitude of colors, perhaps the most glorious of all for cut flower use. Don't neglect to put them out, both in the city and in the country. They will pay for every bit of attention you will give them. We are listing only those we know have proven satisfactory. Take them up in the fall, put in the cellar where they will be kept warm and dry.

Letters following description indicate as follows: "D" Decorative; "C" Cactus; "P" Paonae; "S" show; "HC" Hybrid Cactus. 


\section{DAHLIAS (Continued)}

Delighted. The largest and finest white Dahlia, with immense double blooms 6 to 8 inches across. D

Flamingo. An excellent variety, fine stems clear shell pink. $\mathrm{D}$.

Miss Minnie McCullough. Yellow, heavily tipped red. D

Queen Victoria. Standard yellow.

F. L. Basset. First to bloom, deep lavender or purple. D.
Incomparable. A wonderful ball-shaped Dahlia, nearest a light blue found. S. 75c each.

Jack Rose. American Beauty color. D.

L' Grand anitou. Mammoth, purple, striped and splotched white. D 35c each.

Lyndhurst. Bright scarlet. D.

Orange King. Very early, orange. D. Queen Victoria. The best standard yellow. S.

Sylvia. Pink with white cented. D.

\section{SPRING AND SUMMER BULBS}

Contrary to the general impression we can grow as beatiful flowers here from bulbs as are grown in any more favored climate. Any person who has observed the Noble county park during the past few years must have observed the number and beauty of the various plants there. any of them are bulbs. You can do as well in your garden. Don't fail to take advantage of this method this summer and grow your own flowers. Help in your own way to make a more beautiful country in which to live.

Amaryllis-Hybrid. Variety of colors. A elephant's ear. Largest size bulbs 20c each, wonderful house plant living many, many years. Each 75c.

Caladium, or Elephant's Ear. These plants do not bloom but are valued for their decorative use. Have enormous leaves resembling two for $35 s$.

Tube Rose. Tall spikes of waxy white blossoms, very fragrant and do exceptionally well here. You should grow them. 5c each; 50e per dozen. All the above can be planted in April.

\section{GLADIOLA}

\section{Except where noted all Gladiola $\$ 1.00$ per dozen.}

Soil preparation as for any other bulb. Plant four inches deep. They will surprise you with their responise to a little care.

America. Lavendar pink.

Chicago White. Pure white.

Mrs. Francis King. Flame pink. Mrs. Frank Pendleton. Rose pink on white grown variety. back-ground.

Halley. Delicate salmon pink.

Schwaben. Rich yellow, a spendid easily

\section{CRYSANTHEMUMS}

White Bonaffon, Yellow Bonaffon, White Turner, Yellow Turner, White Mistletoe, Yellow Mistletoe, Pink Seidiewitz, Pink Helen Frick. All 'mums from 2-inch pots price 15e eack: $\$ 1.50$ per dozen.

Anyone can have beautiful 'Mums for their own home. Easily raised, requiring a minimum of care during the summer months. They should be taken up by the first of September, potted and pinched back to the main flowering buds. Plenty of moisture and ordinary care will assure splendid plants. Don't neglect this wonderful flower.

\section{PANSIES}

\section{THE IDEAL PLANT FOR WINTER USE IN THE HOME}

Pansies make one of the finest plants for potting during the winter months. Easily grown withstanding low temperatures which no other plant will endure, and blooming luxuriously all the time; they should be widely used in the home. The price is so low, only $15 \mathrm{c}$ for three-inch potted plants, with a range of colors, that no flower has ever equalled it, and the housewife should insist on buying them right now. They can be planted out of doors at any time the weather moderates, covered with straw and carried for months into the summer.

Our plants are from the finest imported seed, very large, wonderful range of colors. Don't fail to buy now. For spring planting $10 \mathrm{c}$ eacn; $75 \mathrm{c}$ per dozen, postpaid. 


\section{INSECTICIDES}

Nico Dust-The sure kill for all leaf-eating and sucking insects. Nico Dust Gun $\$ \mathbf{1 . 2 5}$ each; Nico Dust 50c per pound; special prices on large quantities.

Paris Green. A poisonous insecticide for insects which chew. When applied as a powder use 1 part Paris Green to 100 parts plaster or flour. As a liquid, 1 part Paris Green to 150 200 gallons water; if used on fruit trees, add 1 pound quick lime. $1 / 41$ ib 20c; $1 / 2$ ib 35 ; 1 ib 50c; 5 th $\$ 2.50$.

Arsenate of Lead. Dry-For dusting and spraying. Solves the problem of effectively combating all leaf-eating insects. 1 it) 50c; 5 in $\$ 2.25$.

Black Leaf 40. A solution of nicotine sulphate, used for soft-bodied sucking insects. For spraying only. Directions must be followed carefully. 1 oz. bottle, 35c.

It is shameful the neglect given our fruit trees, when proper spraying would assure a crop. Most of the failures of fruit crops here, while laid to dry weather. rightfully belong to indifference and carelessness on the part of the orchard owner.

Bordeaux Mixture. Dry-The best fungicide for curing and preventing black rot, mildew, blight, scab, leaf curl and other fungous diseases. 1 ib will make 7 gallons of liquid. 1 ib $40 \mathrm{c} ; 5$ 1b $\$ 1.75$.

Dry Lime Sulphur. For dormant spray use $12-15$ lbs. to 50 gallons water. 1 1b $\mathbf{3 5 c}$; 5 it $\$ 1.50$. $\$ 1.25$

Fly Spray. A certain method of driving flies from milk cows and work horses. 1gallon

\section{ROSES}

We are members of the American Rose Society; and have the privilege of aiding in the dissemination of the new roses distributed from year to year by the United States Department of Agriculture and the Anerican Rose Society. For 1926 two new roses will make their appearance-both "dooryard roses" developed esepecially for all conditions; fit companions of the two wonderful "Dooryard Roses" Heart of Gold and Mary Wallace, which are now being distributed. We are perhaps giving more space to roses than may seem justified, but the rose is so much a part of every home and adds so much to the beauty and livableness of that home, "be it ever so humble," or "sae grand" that we want to do what we can to give to Oklahoma those roses which will do well under every condition. With the experience of the past two years as a guide, growing Mary Wallace and Heart of Gold we believe the series now being brought out solves the problem of having the finest yet the hardiest roses for every home. "Sarah Van Fleet" and "Dr. E. M. Mills," both "Dooryard Roses" will be ready for distribution in the fall of 1926 and spring of 1927. If you love roses, and who does not? secure Mary Wallace and Heart of Gold this spring; then in the fall get at least one plant each of the two new roses.

\section{The Wonderful New Rose "HEART OF GOLD"}

One of the last creations of Dr. Walter Van Fleet before his death. "Heart of Gold" Rose gives to every home garden one of the liardiest and most beautiful roses ever produced. A pillar rose with deep green, shiny foilage which holds late; with great freedom from disease, hardy and vigorous in growth; color of flower, crimson with white at the base of the petals and unusually prominent golden stamens producing a striking effect. It is very floriferous and the buds open in rapid succession. Faded buds drop quickly. It blooms over a considerable season, spring and fall.

Strong 24 inch stems, 2-year-old plants, \$2.00 each.

Your order will receive prompt attention and care and shipment made as rapidly as weather permits. Send in your order at once for this wonderful new rose, "Heart of Gold."

You cannot buy better stock anywhere than we have to offer. Strong, sturdy, two-yearold roses with canes from 18 to 24 inches with heavy roots. We know you will be pleased with the stock and especially with the wonderful range of colors we are offering this year.

Except where noted, all roses 2 years old $75 \mathrm{c}$ each; $\$ 7.50$ per dozen, your own selection. 


\section{HYBRID TEA ROSES-Ever Blooming}

Mary Wallace. Strong grower, blooming profusely in spring, many fine flowers summer and fall; clear rose pink. 2 year $\$ \mathbf{\$ 1 . 5 0}$ each. Strong potted plants $75 c$ each.

Radiance, red or pink.

LaFrance, Pink.

LaFrance, White

-Sumburst, Golden Orange

Maman Cochet, White, pink or red
Columbia, true pink. $\$ 1.00$ each, $\$ 10.00$ per dozen.

Mrs. Aaron Ward, a wonderful rose, coppery orange.

Wm. R. Smith, cream white, shaded pink, splendid.

Ophelia, salmon flesh, shaded rose.

Caroline Testout, Satiny pink.

Killarney, pure white.

\section{HYBRID PERPETUAL ROSES \\ Two year Field Grown Roses, 75e Each, $\$ 7.50$ per dozen}

These roses all do well here. We have them growing in our gardens a mass of bloom in the spring. And with a good showing in the fall. Perfectly hardy, withstand the nunishment of the sun splendidly. Don't fail to set these this spring.
Fran Karl Druschi, red or white.

Magna Clrarta, deep pink.

Grouss An Teplitz, scarlet crimson.

American Beauty, white, nink or red. $\$ \mathbf{1 . 0 0}$ each.

\section{CLIMBING ROSES}

Two Year Field Grown \$1.00 each; $\$ 10.00$ per dozen

We have found these roses will all do well here. Making a strong growtl the first year, the second they completely cover any trellis upon which they are grown. You will not go astray in naming these climbers in your selection.

Mareschal Neil, delicate, rich golden yellow. and of great substance, a wonderful ros.e

American Beauty, pink.

Dr. W. Van Fleet, flesh pink.

Silver Moon, pure white, flower's very large
Grauss An replitz. Searlet crimson, the very best. $75 \mathrm{e}$ each, $\$ 7.50$ per dozen.

Dorothy Perlins. White and pink rambler. - 5 e each, $\$ 7.50$ per dozen.

In addition to the two-year stock we are carrying at our green house, smaller size roses, potted, ready to put in the ground. While they are not as large, nor as sturdy as the field grown roses, yet with some care they will make wonderful plants. Potted in 3 inch pots at $35 \mathrm{c}$ each, $\$ 3.75$ per dozen. Postage paid to you. The varieties listed can be depended on to give the best satis faction in Oklahoma and Southern Kansas.

35c each Postage paid; \$3.75 per dozen. Your selection of Six Favorites \$2.00

Mme. Butterfly. Bright pink, apricot and gold.

Jonkheer J. L. Mock, Clear imperial pink.

Eillarney. Bright pink.

La France. Beautiful, bright, silvery pink.

Mrs. Aaron Wardi. Coppery orange.

Ophelia. Salmon flesh, shaded with orange.

Sunburst. Golden orange.

Lady Hillingdon. Brilliant deep, golden yellow.
Safrano. Bright apricot.

Cimbing Killarney. Deep slell pink.

American Beauty. Well known red. 45e Each.

White American Beauty. The very highest type of white rose. 45c each.

Dr. W. Van Fleet. Delicate shade of flesh pink, deerening to rosy-flesh. 50c each.

Mary Wallace. Bright clear rose pink. 75c each. 


\section{FIELD SEEDS}

Inasmuch as the market changes so radically on small grains for field planting we are not quoting prices at present. However, we shall be pleased to quote you at any time on whatever your requirements may be. During the past five years we have maintained quality in all the field seed we carry. Farmers feel that when they buy of us that they are getting the best the market affords and rightfully so, for we have never, without first knowing exactly what we were buying, made our requisition for field seed stock. Germination and purity are the two most important elements of seed buying. We maintain a high standard for your benefit and protection.

\section{SEED CORN}

Use care in the selection of Seed Corn this spring. The adverse weather conditions of last summer produced very poor seed. We have taken particular care in the selection of our seed corns for this spring's planting. While the cost may be greater than poorly selected seed, yet every farmer knows that the small cost per acre of good seed is the best investment.

We have advocated early corns for Oklahoma. Our contention that the early maturing varieties will fill a long-felt want, is justified.

Don't forget that our Silver Mine is PURE, SELECTED SEED, raised near Perry for the past eight years. That it has made good under every condition and is still making good. Absolutely pure seed, properly cared for, germination guaranteed, nubbed and tipped and recleaned ready for planting. Early planting is necessary for a crop here year after year. $\$ 3.00$ per bushel.

Our EARLY GOLDEN seed has been raised in Noble county for years. Making good year after year. Small cob, long ear, 8 to 10 rows to ear, deep grain, maturing by the first week in July, in the yellow corns it cannot be beaten. $\$ 3.00$ per bushel.

BLUE DENT SQUAW is a reliable corn, raised here for the past few years successfully every year. Our seed is pure, selected, nubbed and tipped. Only pure seed, high germination is sold. $\$ 3.00$ per bushel.

Our other corns are all grown in Oklahoma by the best corn raisers in the country. We take particular pains to see that our seed is pure, and kept pure, year after year, properly cared for, tested for germination. You can't go wrong by buying our seed corns. We list a number of varieties below. $\$ 3.00$ per bushel.

Boone County White.

St. Charles White, red cob.

Silver Mine.

Reid's Yellow Dent.

Mortgage Lifter.

Early Golden.
Blue Dent Squaw.

Blue Squaw.

\section{Strawberry}

Bloody Butcher.

June Corn. White. Ask for prices on all corn. We will gladly send samples.

\section{SORGHUM GRAINS}

The surest of all fodders and grains for Oklahoma. We carry a complete stock of the following :

Pure Dwarf Black Hull Kaffir.

Black Amber Cane.

Red Amber Cane.

Orange Cane.

Red Top or Sumac Cane.

Texas Seeded Ribbon. For sorghum and fodder.

Honey Dip Cane. For sorghum and fodder.
African Millet. Any farmer looking for a new forage crop which will give the best results under all weather conditions can depend on African Millet. This crop is not a true millet, such as German Millet, but really belongs to the cane family. So far as we know it has never been known to kill stock from eating second growth as do some of the canes and it carries more sugar which makes it desirable for hay. A few acres planted this spring will convince the most skeptical that it is a great forage crop. 


\section{SORGHUM GRAINS (Continued)}

German Millet. Our stock of German millet is directly grown from the big lead Tennessee German. However, and this is very important in growing German Millet, the seed should be sown early enough to give $8 .$. opportunity for full development. Late sowings of any millet do not produce good crops, for millet is an early spring crop, doing its best under cool growing conditions. Any millet, whatever its name will not make good crops after hot weather sets in. Very often the best seed of Big Type German will produce small heads and little hay, if sowed late in the spring. This should be taken into consideration by every one planting millet.

Hog Millet.

Sudan.

Sweet Clover. Rapidly coming to the at- tention of every farmer, who realizes that something must be done to improve soil and plant something greatly needed for improving the soil. That element is nitrogen, and sweet clover, while being more and more used for pasture, is being turned under in many places for soil improvement. Don't neglect to put out a few acres this year. Plant in H'ebruary and March, giving same preparation for for alfalfa and using scarified tested seed.

Soy Beans.

Velvet Beans.

Cow Peas. Whip--Poor-Will, Black-Eyed, New Era.

Peanuts. Tennessee Red, Spanish, Virginia.

Pop Coln. Japanese Hulless, Queen's Golden, White Rice.

Prices Subject to Change Without Notice

\section{"Kanota," the Wonderful Productive Oat}

This new Oat, developed by the Kansas State School of Agriculture, has made good.

Ten years in development before being put on the farm for crop purposes, Kanota has proven itself the agricultural find of generations. Remarkably strong in root system and straw, ten days earlier than the old Texas Red, rust proof, has never been known to be killed by the late storms of February and March, producing from 10 to 50 bushels more to the acre than any other oats, it has earned for ifseli the enviable reputation of being the best oat ever produced. Last season it outyielded any other oat, acre for acre; outweighed any oat by 6 to 8 pounds to the bushel.

Our stock is pure. Recleaned. Buying our stock of this remarkable oat assures you of the best seed. Don't delay ordering at once. Sacked in even weight three-bushel bags, at 85c per bushel, f. o. b. Perry, Oklahoma.

\section{SWEET CLOVER-White Blossom}

Don't neglect this great crop this spring. Sweet Clover should be planted as one does Alfalfa; only it can be put, and should be put, in the ground during February and March. The prejudice against it as a weed is rapidly disappearing, as its real worth as a pasture for stock and hogs and its capacity for renewing worn out soils becomes wider known. Aside from this, the seed is rapidly becoming a valuable crop for the demand in the north is greater than the supply. Our seed is the pure white blossom, biennial, scarified, ready for planting. Don't be misled by other seed. Buy our pure, scarified seed for planting this spirng.

We have investigated the best methods of planting Sweet Clover; getting the results of the different methods of planting from the farmers who are actually trying to get the best results from their planting. Experience has proven that the old methods of throwing the seed on turf or plowed ground; planting with oats or wheat as a nurse crop are not successful; but that the proper way to plant is the same preparation as for alfalfa; planting with a grain drill and giving every opportunity for growing which proper preparation will give.

Pure scarified White Blossom Sweet Clover. Special prices on large quantities. Get our prices before buying elsewhere.

Sweet Clover is much cheaper this year than ever before. While we cannot guaranteo prices, our judgment is that seed will sell from $\$ 4.25$ to $\$ 8.50$ per bushel, depending on quality.

\section{Our prices will compare favorably with out-of-state firms at all times, meaning a real saving to you}




\section{ALFALFA \\ The Wonder Crop For All Climates}

Our alfalfa seed is Oklahoma grown. We are not selling imported alfalfa seed, for several reasons, though it can be bought cheaper than native seed; chief reason being that we do not want to be instrumental in disseminating unknown noxious weeds throughout Oklahoma.

Get our prices on different grades before buying elsewhere.

This issue of our "SEED BUYERS GUIDE" is going into thousands of farm homes this year. We are a young seed firm. We are certain that an order will convince you that we are real seedmen, that the quality of our seeds is the very best; that we have succeeded in giving you the best seeds for our climate. Use our order blanks for real service in seeds.

\section{BLACK HULL KAFFIR}

Our strain of Black Hull Kaffir has been grown for us for the past eight years. This Kaffir is a real picture in the field. Standing 4 to $4 \frac{1}{2}$ feet in height, heavy stalks and foliage, heads even, compact, with never one showing above the other, a field in head is a wonderful sight.

Pure strain, selected and recleaned, ready for immediate planting at proper time. Our seed this year will show a test of $95 \%$ germination, $100 \%$ purity. Don't fail to get your kaffir seed from us. Write for prices in small and large quantities, samples gladly mailed on request.

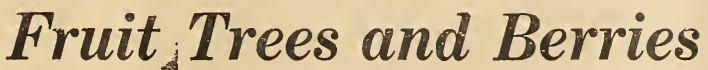

We are carrying a complete list of fruit trees suitable to Oklahoma conditions. While the list is not as complete as that of the large nurseries yet it is complete so far as the varieties which can be depended on here. We are giving particular attention to shipping preparations that your order may reach you in best of condition. Use order blank in front of catalog. Apples: Ben Davis, Delicious, Gano, Stayman. Winesap, Mammoth Black Twig, Grimes Golden, Early Harvest. Prices :

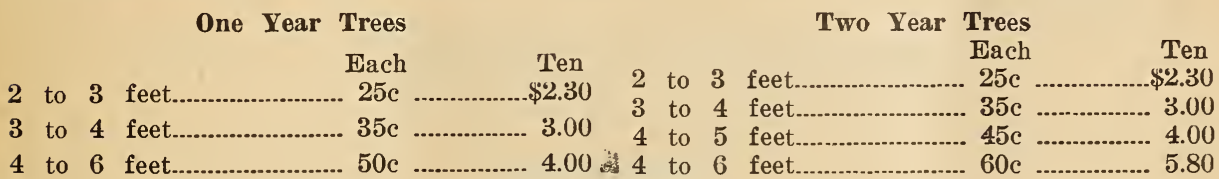

Peaches: Crawford Early, Champion, Crawford Late, Early Elberta, Elberta, Heath Cling, J. H. Hale, Triumph. Prices :

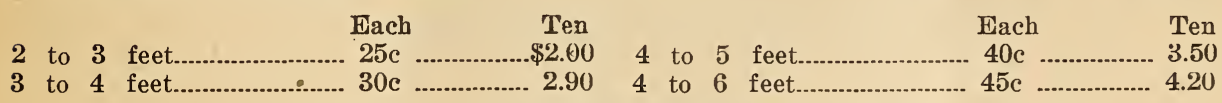

Japan Blood Dwarf, 25c each higher in all grades

Pear: Duchess, Garber, Keifer. Prices:

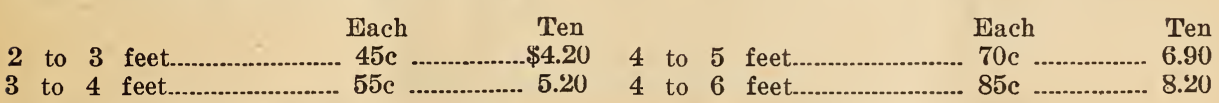

Cherries: Dyehouse, Early Richmond, English Morello, Montmorency. Prices:

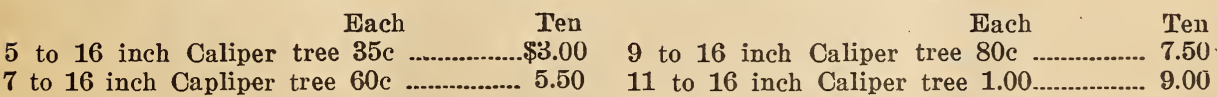

Compass Cherry Plum: Prices: Each 45c, 60c, 75c, \$1.00. Ten: $\$ 4.00, \$ 5.50, \$ 7.00 \$ 9.00$. Plums: Abundance, Burbank, Red June, Shiro, Wickson, Wild Goose. Prices:

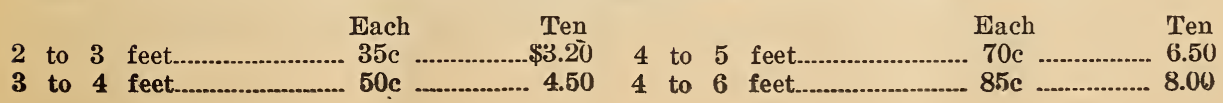


Apricot: Alexander, Early Golden, Royal, Superb. Prices :

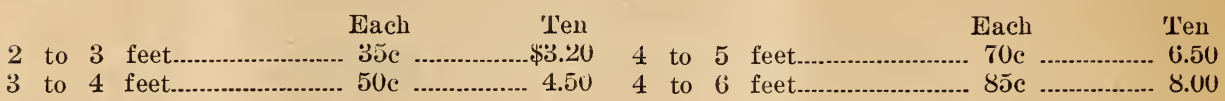

Blackberries: Early Harvest, McDonald, Mercereau. Prices: 10c each, 75c for 10, \$4.00 per 100 and $15 \mathrm{c}$ each, $\$ 1.00$ for $10, \$ 7.00$ per 100 .

Raspberries: Cumberland, 10c each; 9ve for 10; \$7.50 per 100. St. Regis, 25e each; \$1.50 for $10 ; \$ 10.00$ per 100 . Cuthbert $15 \mathrm{c}$ each; $\$ 1.00$ for $10 ; \$ 8.50$ per 100 .

Dewberry: Lucretia, 10c each; 60c for 10 ; $\$ 5.00$ per 100 . Austin, 10c each; 60c for 10; $\$ 5.00$ per 100.

\section{STRAWBERRIES}

We can furnish you with the following varicties: Klondyke, Aroma, America, Dunlap. Progressive Everbearing: 50 plants $\$ 1.00 ; 100$ plants $\$ 1.50 ; 500$ plants $\$ 7.00: 1.000$ plants $\$ 13.00$.

Strawbery: Senator Dunlap, Amerisă, Klondyke. 5ue fur $20 ; \$ 1.00$ per 100; $\$ 6.00$ per 1000.

\section{Shrubbery for the Home}

Oklahoma homes can be made, at little expense, as beautiful as the homes of those states having a better climate. 'There are shrubs which will endure every aegree of hot and dry weather. Flowering shrubs add immeasureably to the beauty of the home; add to its value should the time come when one desires to dispose of it.

Our stock is the best obtainable. We have been adding to our growing stock until we now have shrubbery of many kinds acclimated to Oklahma conditions. We have them in stock. Your order will be carefully filled and shipped to you the day received, weather conditions permitting.

\section{SPIREAS}

VanHoutti, Bridal Wreath, Spirea, pure white; Anthony Watterer, pink, summer blooming; Billardie, pink :

12 to 18 inch Shrubs 35e each; dozen $\$ 3.50$

18 to 24 inch Shrubs 50c each; dozen $\$ 5.00$

24 to 36 inch Shrubs 65c each; dozen $\$ 7.00$

\section{WEIGELIAS}

Shrubs bloom in July, very hardy. Rosea, Lwarf grower adapted to small gardens. Eva Rathke, the very best, flowers all summer and fall, a rich ruby carmine.

18 to 24 inch Shrubs 50e each; dozen $\$ 5.00$

24 to 36 inch Shrubs 85 each; dozen $\$ 8.50$

\section{DEUTZIAS}

Easily grown here making wonderful growth and blooming first season if set early. Pride of Rochester, white flowers, large and double blooming very early:

18 to 24 inch Shrubs $45 \mathrm{e}$ each; dozen $\$ \mathbf{4 . 5 0}$

24 to 36 inch Shrubs 60 e each; dozen $\$ 4.50$

\section{GOLDEN BELL}

The golden yellow flowers appear in early spring making a wonderful display when there are few other flowers. Heavy green foilage throughout the summer. Intermedia.

18 to 24 inch Shrubs 35e each, dozen $\$ 3.50$

24 to 36 inch Shrubs 65e each; dozen $\$ \mathbf{\$ 7 0 0}$

\section{SNOWBALL}

One of the choicest, hardy shrubs, growing to advantage on the north side of the home where few other shrubs do well. 


\section{HYDRANGEA (Snow Ball)-Hills of Snow}

Fasily grown. valuable for hedoing or for clumps.

Pure white. covered with blossnms through July and August. 2-year plants 75c each; $\$ 6.00$ per dozen. Special prices en larger amounts.

Paniculata, The hardiest of all, blooming the entire season.

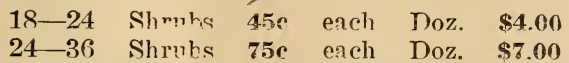

\section{BUTTERFLY BUSH}

One of the most resirable summer flowerino shrubs. Blooming in July, color violet-mauve. No. 1 size Shrubs 6.50 each Doz. $\$ \mathbf{\$ 7 . 0 0}$

\section{JAPAN QUINCE}

The scarlot red Alwers arronr hefo"e the leaves. One of the very best. 2-3 ft. Shrub ase each Doz. $\$ 7.00$

\section{Brooder Stove Coal}

\section{Use Anthracite Coal This Brooding Season}

We are stocking anthracite brooder coal for the first time this growing season. The demand has been heavy for this coal but the cost has heretofore made it almost impossible for us to handle it so the average chicken grower could buy it.

Price: Anthracite Brooder Coal, sacked $\$ 1.00$ per $100 \mathrm{lb}$ in any quantity Loose, $\$ 18.00$ per ton. All F. O. B. Perry. We can ship this coal to any customer in any quantity, any where.

\section{Treeman \& Munger, Perry, Okla.}

seses

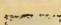

\section{SPECIAL NOTICE}

How to Order and Remit: Tse the order sheet enclosed in catalog. Write your name, post office address or nearest express office CAREFULIIY. Last rear several orders were delayed because the name of person ordering failed to appear on order sheet. So do not neglect this.

On all orders for small garden seed we will prenary the postage or express. This does not include peas, beans, corn, etc.: for which remittance should be made on the basis of zones. In the first one which is within 50 miles of Perfy, $7 \mathrm{c}$ 1st pound and 1c for each additional to. pound.

Second zone which is within 150 miles of Perry, 7c 1st pound and $2 \mathrm{c}$ for each additional

Third zone which is within 150 to 300 miles of Perry, 7c 1st pound and 3c for each additional pound.

F'rom this table one should be able to estimate the amount of postage which is necessary to carry your parcel. Please do not neglect this for it means real service for you if the postage is included. The weight limit within these zones is 70 pounds. Freight and express rates are cheaper than parcel post rates in larger quantities.

Payment for all orders should be made by either post office money order, express money order, certified check or by registered letter. If goods are to be sent C. O. D. o rsight draft bill of lading attached, 25 percent of the order should accompany the order. This serves as both a protection to you and to us and is not intended to work a hardship in any way.

Let's all pull together for diversification of farm and garden crops and get out of the "tin can living" to which so many are heading. The only way it can really be accomplished is to raise more and better garden products; and to see that plenty of fodder erops are planted, diversified also, giving the cow and the hen a chance to help out. Plant a "patch" of corn or cotton, if it is only a few acres-it may do wonders. Success can be summed up in one word.

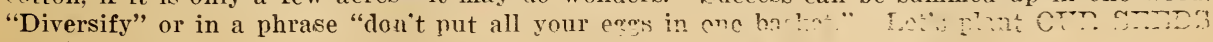

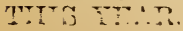




\section{THE ROYAL BROODER}

\section{FOR LITTLE CHICK RAISING}

Every poultry raiser knows there are certain requirements for the raising of little chicks PROFITABLY, that must be met. There are certain requirements in a stove.

\section{The Capacity for Heating.}

The Royal Brooder Stove is built in two sizes-500 eapacity and 1,000 capacity. It is built of the best iron, strong, rigid, wearing, lasting materials. Flue is $\mathbf{5}$ inches in diameter, thereby carrying a regular cook stove or heating stove pipe. WE FURNISH THE FIRST JOINT WITH EACH STOVE SOLD, Not a little 4 inch pipe which clogs with soot, allows the fumes to escape in the brooder house, dampens the pipe and the walls of the chicken house and forces the fire to die for lack of plenty of draft-BUT-a

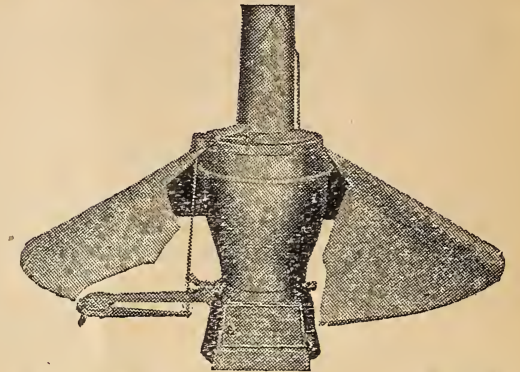

500 Capacity $\$ 21.75$

1.000 Capacity.

(F. O. B. Perry)

full size stove pipe which cares for all necessary draft, escape for smoke and fumes and soot and by its own heat prevents the accumulation of moisture on the pipe and in the house. These points are well worth your time and trouble to investigate.

\section{Fuel Capacity.}

Any good coal can be used in the Royal Stove-and is as easily controlled as with an expensive coal: The coal chamber is very large thereby giving assurance of heat in the worst weather, which every chicken raiser knows comes in the cold, damp days of early spring.

3. Thermostat Must be Rigid and Strong.

The heat regulator, called the thermostat, is constructed rigidly and in such a way that nothing can interfere with its action in the coldest weather. It absolutely controls the heat.

4. The Hover is Strong, Reinforced and Rigid. No amount of ordinary weight falling on it can bend the galvanized iron, reinforced hover.

THESE POINTS ARE WORTHY OF INVWSTIGATION. See the Brooder on display, or we will ship to you, safely packed f. o. b. Perry, Oklahoma, at above prices.

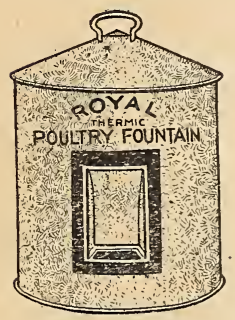

\section{THERMIC POULTRY FOUNTAIN}

Once used, never without. Every progressive poultryman knows that WATER, lots of water, is absolutely essential to egg production. Our fountains keep water WARM ALL DAY in the coldest weather. Clean, sanitary, lasting. An absolute necessity.

Two Gallon Size.

F! O. B. Perry, Crated for Shipment

\section{POULTRY ACCESSORIES}

These Feeders and Waterers are supplies which every poultry raiser needs. Cheap, easily cleaned, sanitary, feed savers. Don't go through the season without them.

Mason Jar Waterer 15e Each; Two for $25 \mathrm{c}$

Feeders, 20-hole size 35c each; 10-hole size 20c each Postage or Express Extra at Cost

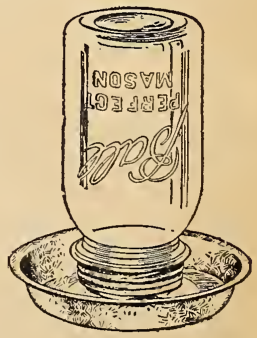

\section{STEEL BROODER CQOPS}

Our Brooder Coops are made of heavy galvanized iron, three sets of doors for all kinds of weather conditions, rat-proof, varmint-proof, fool-proof sufficient for one hen with brood of thirty chickens. Don't be misled on other cheaner constructed coops. These are worth the money. Only $\$ 1.50$ each, f. o. b. Perry. 
We are sole agents in Noble county for the famous Queen Incubators and Brooders, both coal and oil burning.

\section{The Queen Incubator}

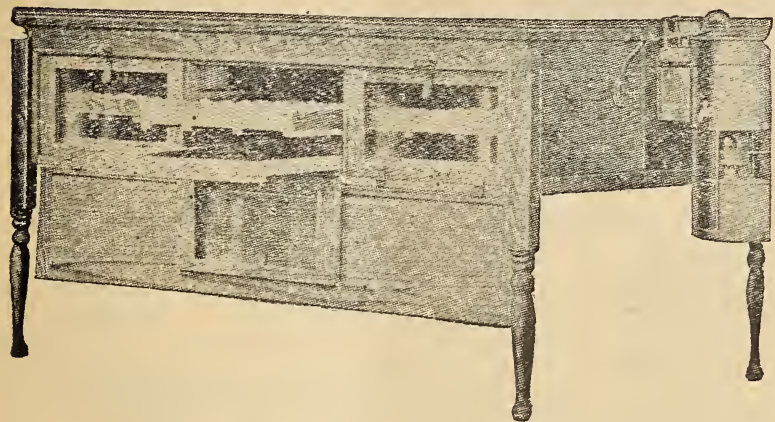

The Queen is higher priced than some other makes on the market, necessarily so; for it represents the highest type incubator construction. It is made of the finest materials. Queen incubator proves its economy by year after year of hard service such as cheaper machines cannot possibly give.

We carry the Queen Incubator in sizes ranging from 135-egg capacity to 600-egg capacity.

We carry the Queen oil burning Brooder and coal burning Brooder Stoves in 300,500 and 1,000 capacity..- There are no better brooders made.

\section{Prices on request for all sizes of Incubators and Brooders.}

We have a special plan which will enable anyone who wants the best in poultry equipment to own our Queens, Incubators and Brooder, and Royal coal burning stoves. There is real money in poultry. And there is financial freedom in poultry. If you care to take advantage of the plan we shall be pleased to help you make Noble county, Northern Oklahoma and Southern Kansas the center of the hen world.

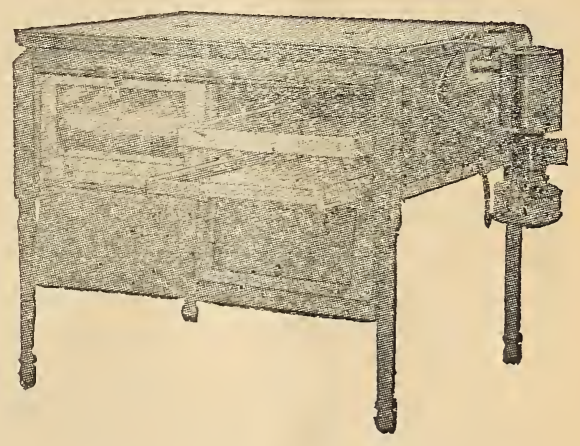

\section{Make all inquiries direct to Treeman \& Munger, Poultry Depart- ment, Perry, Oklahoma}

Chicken Necessities which should be in every Poultryman's hands.

Charcoal-Little chick size and hen size, each.......................................10e per pound, $3 \mathbf{m}$

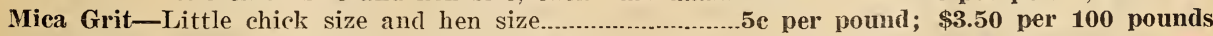
Oyster Shell-Pure, clean, dry shell. Reef brand. $\$ 1.35$ per 100 lbs. Special prices on large quantities. Don't hesitate to get our quantity prices.

60\% Protein 'Tankage, Blue Ribbon

per 100 pounds, $\$ 4.75$

$60 \%$ "Flox" Meat Seraps, Blue Ribbon. per 100 pounds, \$5.25 F. O. B. Perry, Oklahoma. These are necessities for egg production and rapid growth of chicks. Don't be without them. Prices subject to change without notice. 


\section{Day Old Baby Chicks}

Baby Chicks Hatched from Eggs from Finest Flocks in Noble County.

All chicks are hatched in the Famous Buckeye and Queen incubators which absolutely guarantees healthy chicks of great vitality.

Noble County, Oklahoma, is third in the production of eggs and chickens in Oklahoma. The flocks of Leghorns, Reds, Rocks and all other standard breeds in Noble county have been improved for many years by the purchase of blood from the finest flocks in the United States and Canada. High prices have been paid for cock birds for many years to head prize winning pens; and as a result the flocks in Noble county have benefitted; until today Noble county chickens are prize winners in some of the biggest shows in the West. As layers Noble county flocks have no competitors. In the White Leghorn class, for many years the finest cockerels in England were imported and crossed with trap-nested hens. This has given an impetus to egg production which has made Noble county third in Oklahoma in the production of eggs.

Our chicks are hatched from eggs from such flocks as we know through the years have felt the influence of proper breeding, proper feeding and housing. We know that they are properly mated for fertility before we contract for our eggs for hatching. All these things assure the purchaser of our baby chicks they are buying strong, sturdy chicks from a breeding standpoint; and the fact that they are hatched in the Brckeye Mammoth 12,500 capacity machine and the smaller size, but no less efficient Queen incubato's gives to our customers the best there is in baby chicks.

The further fact that Perry is centrally located with twelve passenger trains daily carrying express gives us an opportunity to make shipments which will deliver the chicks to your local postoffice in one day, or less time.

Our first hatch comes off Febuary 1st, and from then on daily. Your order will be cared for, and shipment made as near the date you want them as it is possible to make it. Prices below are for cash with order. No orders accepted under any other terms unless special arrangement be made for partial payment at time of order, balance on date of and preceeding shipment.

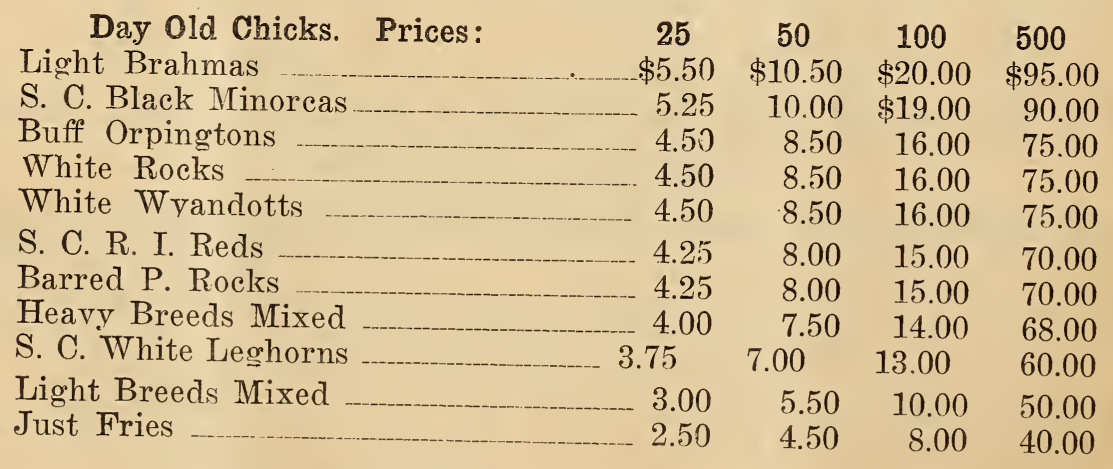



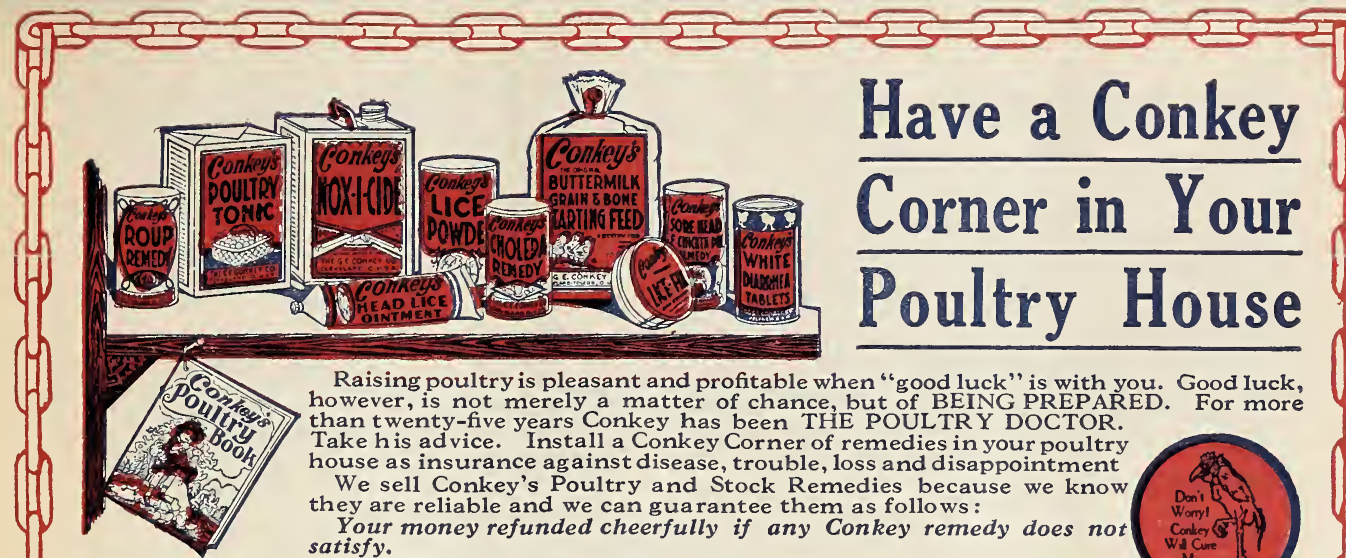

Raising poultry is pleasant and profitable when "good luck" is with you. Good luck, however, is not merely a matter of chance, but of BEING PREPARED. For more than twenty-five years Conkey has been THE POULTR Y DOCTOR. house as insurance ag ainst disease, trouble, loss and disappointment We sell Conkey's Poultry and Stock Remedies because we know they are reliable and we can guarantee them as follows:

Your money refunded cheerfully if any Conkey remedy does not atisfy.

CONKEY'S POULTRY BOOK FREE if you call at our store, or mailed for 6 cents in stamps.

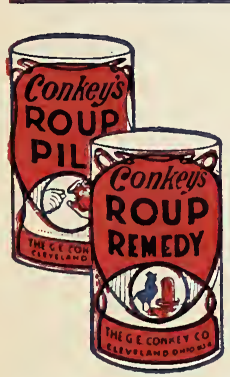

\section{Conkeys \\ Roup Remedy}

When $\mathrm{R}$ o u p breaks out there's no time to experiment - start treatment at oncethe disease is very contagious. Cold, rainy weather and changeable conditions intensify Roup. When birds sneeze, froth in eyes, or run at nose put Conkey's Roup Remedy in the drinking water Sick birds doctor themselves and others are protected from catching the disease. Better still, always at the first sign of "roupy weather" place Conkey's Roup Remedy in fountains-it's a great preventive.

PRICES-Pkgs. $30 \mathrm{c}, 60 \mathrm{c}, \$ 1.20$; or $35 \mathrm{c}, 65 \mathrm{c}, \$ 1.30$ postpaid; $11 / 2 \mathrm{lb}$. can $\$ 2.50$ postpaid; breeder size (5 lb. can) $\$ 5.75$ postpaid. These prices prevail in both Eastern and "Colorado and West" territory.

\section{Conkeys Roup Pills}

For treating individual cases and for use at shows when birds develop colds.

PRICES-Pkgs. $30 \mathrm{c}, 60 \mathrm{c}, \$ 1.20$; or $35 \mathrm{c}, 65 \mathrm{c}, \$ 1.30$ postpaid; breeder size (1000 pills) $\$ 3.00$; or $\$ 3.10$ postpaid. These prices prevail in both Eastern and "Colorado and West" territory.

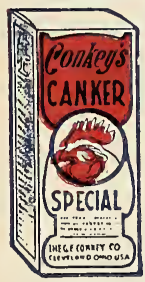

\section{Conkeus' Canker and} Bronchitis Remedy

This splendid remedy checks cankerous growths and sores and soon restores the bird to normal. This remedy is Conkey's Specific for bronchitis. Also desirable in treating individual cases of Roup.

EASTERN PRICES: Pkg., 50c; pt., $\$ 1.20$; qt., $\$ 2.00$; gal., $\$ 7.00$. All sent carrying charges extra.

COLORADO and WEST: Pkg., 60c; pt., \$1.45; qt., $\$ 2.40$; gal., $\$ 8.00$. All sent carrying charges extra.

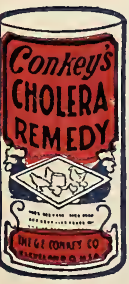

\section{Conkeus's}

\section{Cholera Remedy}

So-called Cholera, bowel troubles, indigestion, diarrhea and kindred ailments often kill a whole flock in a few days. Diarrhea, a drowsy, listless appearance and great thirst-these are the signals to put Conkey's Cholera Remedy in the water.

EASTERN PRICES-Pkgs. 25c, 50c, $\$ 1.00$; or $30 \mathrm{c}, 55 \mathrm{c}, \$ 1.10$ postpaid : breeder size (5 lbs.) $\$ 2.50$; or $\$ 2.65$ postpaid.

COLORADO and WEST-Pkgs. 30c, 60c, $\$ 1.20$; or $35 \mathrm{c}, 65 \mathrm{c}, \$ 1.30$ postpaid; breeder size (5 lbs.) $\$ 3.00$; or $\$ 3.15$ postpaid.

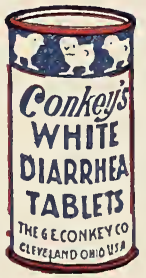

Conkeys White

Diarrhea Remedy

Once you have used this old reliable preparation you will never be without it. As a preventive of bowe troubles, White Diarrhea and other digestive complaints, it has given great satisfaction for many years. Once started diarrhetic conditions often sweep away the whole hatchhundreds of chicks. Play safe-keep this remedy in the drinking water until the danger period is past. This remedy is also recommended as a preventive measure and for reatment of coccidiosis.

PRICES-30c, $60 \mathrm{c}, \$ 1.20$; or $35 \mathrm{c}, 65 \mathrm{c}, \$ 1.30$ postpaid. Breeder size $(1200$ Tablets $), \$ 4.00$; or $\$ 4.10$ postpaid. These prices prevail in both Eastern and "Colorado and West" territory.

\section{Conkeys' Poultry Laxative}

Wherever a laxative or purgative is needed this remedy is just the thing for birds-by varying the dosage you can produce either a mild or a strong effect. Works without a debilitating after-effect. Experts say, and we have found through experiments, that a poultry laxative given every week or two not only keeps birds in better condition but increases the egg yield.

EASTERN PRICES-Pkgs, 25c, 50c: or 30c, 55c postpaid; breeder size (5 lbs.), $\$ 2.75$; or $\$ 2.90$ postpaid.

COLORADO and WEST-Pkgs. $30 \mathrm{c}, 60 \mathrm{c}$; or $35 \mathrm{c}$, 65 c pcitpaid; breeder size, $\$ 2.75$; or $\$ 2.90$ postpaid.

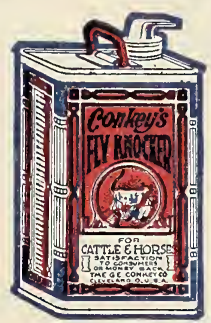

\section{Conkeuss}

\section{Fly Knocker} for Cows and Horses

Dairymen, horsemen, cattlemen and sheep raisers declare this remedy the best investment they make; animals free from insects do better in milk and butter fat production, while growing stock unquestionably fattens faster when relieved from diseasespreading i nsects.

Conkey's Fly Knocker for many years has held the confidence of persons having animals under their care as an "always reliable" repellent.

We sell Conkey's Fly Knocker on this guarantee:

Buy a can; try it for 15 days, then if you are not satisfied we will refund your money.

EASTERN PRICES-Cans, qt. 60c; $1 / 2$ gal. 90c gal. $\$ 1.50 ; 5$ gal. $\$ 7.25 ; 10$ gal, $\$ 14.00$. Parcel post, express or freight extra.

COLORADO and WEST-Cans, qt. 70c; $1 / 2$ gal $\$ 1.15 ;$ gal. $\$ 1.75 ; 5$ gal. $\$ 8.00 ; 10$ gal. $\$ 15.50$. Parcel post, express or freight extra.

\section{.}




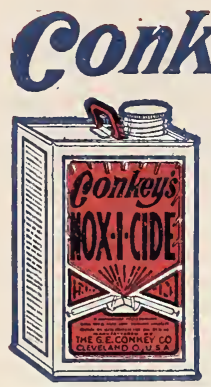

For Poultrymen, Conkey's Nox-i-cide has a large variety of uses. For spraying during the "weekly cleanup," as a preventive of disease and a help in keeping down red mites, ticks, blue bugs, etc., Conkey's Nox-i-cide is practically unexcelled.

Conkey's Nox-i-cide is also widely used and highly recommended as a dip for hogs, sheep, cattle and other animals. Swine owners are generous in their praise of Conkey's Nox-i-cide for fighting hog lice, both as a dip and as a disinfectant for wallows, houses and general uses.

Also used as a general household disinfectant.

EASTERN PRICES-Pint 50c; Quart $80 \mathrm{c}$; $1 / 2$ Gallon $\$ 1.30$; Gallon $\$ 2.00 ; 5$ Gallons $\$ 9.25 ; 10$ Gallons $\$ 17.75$. Parcel post, express or freight charges extra.

COLORADO and WEST-Pint 50c; Quart 80c; $1 / 2$ Gallon $\$ 1.30$; Gallon $\$ 2.00$; 5 Gallons $\$ 9.50 ; 10$ Gallons $\$ 18.00$. Parcel post, express or freight charges extra.

\section{Conkeys's Sorehead Remedy}

For dangerous, contagious sorehead or chicken pox, pigeon pox, warts and pian. Attacks the trouble from two angles-a powder for the blood and a salve for the sores.

EASTERN PRICES-Pkgs. 25c, 50c; or 30c, 55c postpaid; breeder size ( $1 \mathrm{lb}$. salve, 5 lbs. powder), $\$ 3.50$; $\$ 3.65$ postpaid; 10 lbs. powder only, $\$ 3.50$; $\$ 3.65$ postpaid.

COLORADO and WEST-Pkgs. $30 \mathrm{c}, 60 \mathrm{c}$; or $35 \mathrm{c}$ 65 c postpaid; breeder sizes, $\$ 3.50 ; \$ 3.65$ postpaid.

\section{Conkeys Gape Remedy}

Two different powders-both in same box for one price-one sifted over chicks forces them to cough up parasites, the other is a tonic to put in feed.

EASTERN PRICES-Pkgs. 25c, 50c; or 30c, 55c postpaid.

COLORADO and WEST-Pkgs. $30 \mathrm{c}, 60 \mathrm{c}$; or $35 \mathrm{c}$, 65 c postpaid.

\section{Conkey's Poultry Conditioner}

Highly-concentrated fowl regulator, blood purifier and nerve food for run-down birds and conditioning show birds.

EASTERN PRICES-Pkgs. 25c, 50c; or 30c, 55c postpaid.

COLORADO and WEST-Pkgs. $30 \mathrm{c}, 60 \mathrm{c}$; or $35 \mathrm{c}$, $65 \mathrm{c}$ postpaid.

\section{Conkeys's Limberneck Remedy}

EASTERN PRICE-Pkg. 50c; or 55c postpaid. COLORADO and WEST-Pkg. 60c; or 65c postpaid.

\section{Conkeyss Blackhead Remedy}

Should be given regularly to growing poults. EASTERN PRICES-Pkg. 50c; or 55c postpaid. COLORADO and WEST-Pkg. 60c; or 65c postpaid.

\section{Conkeys' Lice Fix}

A preparation in ointment form for fighting body lice. One application lasts a month.

EASTERN PRICES-Pkgs. $25 \mathrm{c}, 50 \mathrm{c}$; or $30 \mathrm{c}, 55 \mathrm{c}$ postpaid.

COLORADO and WEST-Pkgs. $30 \mathrm{c}, 60 \mathrm{c}$; or $35 \mathrm{c}$, 65 c postpaid.

\section{Conkeys's Head Lice Ointment}

EASTERN PRICES-Pkgs. 10c, 25c; or 15c, 30c postpaid.

COLORADO and WEST-Pkgs. 15c, 30c; or 20c, 5c postpaid.

\section{Conkeys Lice Powder}

(Contains Sodium Fluoride)

EASTERN PRICES-Pkgs. 20c, 35c, 75c; pails 12 lbs. $\$ 2.60 ; 25$ lbs. $\$ 5.00$. Parcel post, express or freight extra.

COLORADO and WEST-Pkgs. 25c, 45c, 90c: pails 12 lbs. $\$ 3.00 ; 25$ lbs. $\$ 5.75$. Parcel post, express or freight extra.

\section{Conkeys' Mite Liquid}

PRICES-Cans, qt. 60c; 2 qt. $90 \mathrm{c}$; gal. $\$ 1.50$; 5 gal. $\$ 7.00$. Parcel post, express or freight extra. These prices prevail in both Eastern and "Colorado and West" territory.

Conkeys's Scaly Leg Remedy

EASTERN PRICE-Pkg. 25c; or 30c postpaid. COLORADO and WEST-Pkg. 30c : or 35c postpaid.

Conkeys' Poultry Worm Remedy

EASTERN PRICES-Pkgs. 25c, 50c; or 30c, 55c postpaid; breeder size (5 lbs.), $\$ 2.75$; or $\$ 2.85$ postpaid.

COLORADO and WEST-Pkgs. $30 \mathrm{c}, 60 \mathrm{c}$; or $35 \mathrm{c}$, 65 c postpaid; breeder size $\$ 2.75$; or $\$ 2.25$ postpaid.

\section{Conkeys Y.O.}

\section{Yeast With Cod Liver Oil}

This combination, being a blend by a patented, Conkey process, gives the poultryman cod liver oil and yeast in a cheap, handy, practical way.

The product, a chocolate brown, coarse, freerunning powder, easily mixed with any poultry mash, supplies vitamins A, B and D, needed for better egg production, better fertility, increased hatchability, more vigorous chicks and faster growth.

EASTERN PRICES-Pkgs. 1 lb., \$1.00; 2 lbs.; $\$ 1.75 ; 5$ lbs., $\$ 4.00$; all postpaid. The following larger sizes will be sent parcel post, express, or freight charges extra: $25 \mathrm{lb}$. drum, $\$ 18.75 ; 50 \mathrm{lb}$. drum, $\$ 32.50$; $100 \mathrm{lb}$. drum, $\$ 60.00$.

These prices prevail in both Eastern and Colorado and West territory.

Tell us size of your flock and we'll tell you how much to buy.

\section{Conkeyss Stock Tonic}

EASTERN PRICES-Pkgs. 25c, 50c, \$1.00; pails, 12 lbs. $\$ 2.10 ; 25$ lbs. $\$ 3.45$; bags, 50 lbs. $\$ 5.25 ; 100$ lbs. $\$ 10.00$. Parcel post, express or freight charges extra.

COLORADO and WEST-Pkgs. 30c, 60c, $\$ 1.20$ : pails, 12 lbs. $\$ 2.50$ : 25 lbs. $\$ 4.25$; bags, 50 lbs. $\$ 6.25$ : 100 lbs. $\$ 11.50$. Parcel post, express or freight charges extra.

\section{Conkeys POULTRY TONIC}

Helps birds get more out of their feed; they produce more eggs and better flesh on LESS FEED, by better dicstion and assimilation. Conkey's Tonic is all medicine-free from filler, red pepper, and "hot stuff" to overstimulate the birds and break down their health. Conkey's builds on a natural, healthy basis, inducing steady and persistent laying. Keeps the young chicks growing, makes molting easy, strengthens the bird for bad weather and generally maintains a high health average.

EASTERN PRICES-Packages, 11/2 lbs., 25c; 31/4 lbs., 50c; 7 lbs. $\$ 1.00$; pails, 12 lbs., $\$ 1.60 ; 25$ lbs., $\$ 3.00$; bags, 50 lbs., $\$ 5.00 ; 100$ lbs., $\$ 9.50$. Parcel post, express or freight charges extra.

COLORADO and WEST-Packages, 11/2 lbs., 30c; $31 / 4$ lbs., 60c; 7 lbs., $\$ 1.20$; pails, 12 lbs., $\$ 2.00 ; 25$ lbs., $\$ 3.50$; bags, 50 lbs., $\$ 6.00 ; 100$ lbs., $\$ 11.00$. Parcel post, express or freight charges extra. 


\section{Dusen \\ OIL BURNING BR00DER \\ (WITH THE 2ueen GuARantee)}

We can now offer Poultry Raisers an OIL BURNING BROODER with the Queen Guarantee.

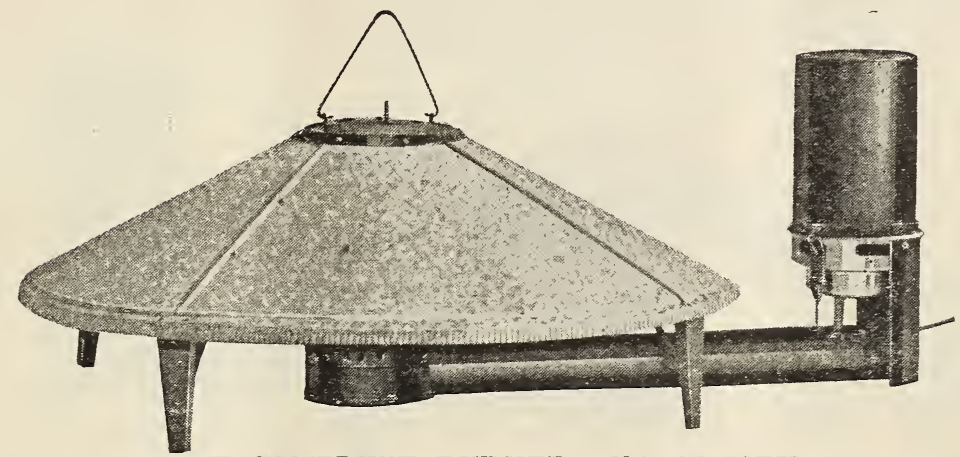

THE COMPLETE BURNER AND CANOPY

Heary Galvanized Iron Canopy, ventilated through dome on top. Shipped dissembled. Easily put together.

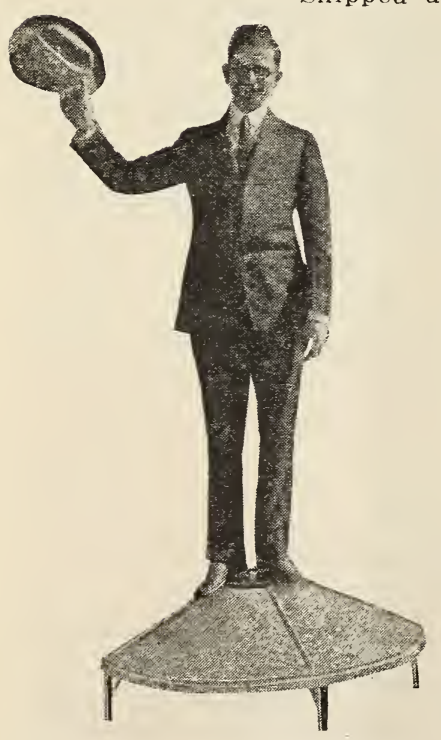

PROOF OF ITS STRENGTH Bears the weight of a heavy man. Edges beaded and crimped.
It has been submitted to every conceivable test and has proven its efficiency. It is SIMPLE, DURABLE and SERVICEABLE. BUILT TO LAST.

The canopy is made from heavy galvanized iron, with a special beading and crimping process on the edge which adds greatly to its strength and rigidity.

The top ventilator provides a good circulation of heat and air at all times.

QUEEN INCUBATOR CO. LINCOLN, NEBRASKA

Printed in U. S. A. 


\section{Broods Chicks That Live}

\section{and Grow}

\section{REQUIRES LITTLE ATTENTION. PLENTY OF HEAT WITHOUT DANGER}

Clean the wick occasionally. Refill the tank every 48 hours, and it will take care of itself. Nothing to break.

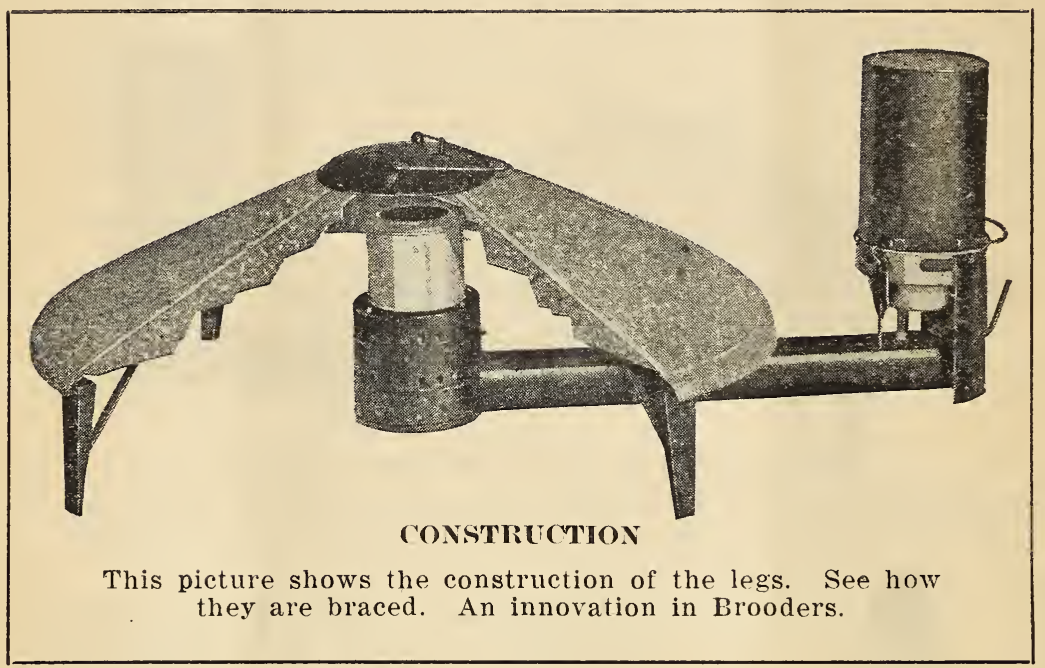

Wick of indestructible asbestos. No solder used on burner. All welded. Leaks almost impossible. Oil cannot overflow burner. Attractive guard around burner and cross pipes.

Two gallon metal tank. Will burn 48 hours without refilling. Metal tank minimizes fire risk. No overflowing. No bottle to break. Few moving parts. All visible. Strong and rugged. Parts seldom need renewal.

300 Chick size (wt. 35 lbs.), 32-inch Hover

600 Chick size (wt. 40 lbs.), 42 -inch Hover-_- 20.00

1000 Chick size (wt. 45 lbs.), 52-inch Hover22.50 Higher west of the Rocky Mountains in Canada and certain parts of Texas. 


\section{The Planter's Guide}

TIME REQUIRED FOR MATURITY OF DIFFERENT GARDEN CROPS RECKONED FROM DAY OF PLANTING

Days

Beans-String..........45 to 65

Beans-Shell.............65 to 75

Beets-Table............. $\quad \mathbf{6 5}$

Beets-Stock........100 to 120

Cabbage-Early ............ 105

Cabbage-Late .............. 120

Cauliflower

110

Days

Corn

.70 to 120

Egg Plant .............150 to $\mathbf{1 6 0}$

Lettuce-Heading ............ 65

Melon-WVater ....120 to 140

Melon-Musk ....120 to 140

Onion ................135 to 150

Pepper ..................140 to 150
Days

Radish .30 to 40

Squash-Summer....60 to 65

Squash—Winter............... 125

Tomato................................ 150

Turnip.......................60 to 70

Spinach, average.......45 to 65

\section{AVERAGE AMOUNT OF GARDEN SEED AND NUMBER OF PLANTS FOR ONE ACRE}

Asparagus plants, $4 \times 11 / 2 \mathrm{ft}$. .7790

Beans, bush, in drills, 21/2 ft..........11/2 bu.

Beans, Pole, Lima, $4 \mathrm{x} 4 \mathrm{ft..........................}$

Beets and Mangels, in drills, 21/2 ft........6 lbs.

Cabbage, sown in outdoor beds for transplanting ............8 oz.

Cabbage, sown in frames ......................4 oz.

Carrot in drills 21/2 ft. ................................ 4 lbs. Celery Seed .....................8 oz.

Celery Plants, $4 \mathrm{x}^{1} / 2$ ft................................. 20.000 Corn, sugar....................8 qts, Corn Salad in drills, 10 in., large seed...25 lbs. Cucumber's in hills, $3 \mathrm{x} 4 \mathrm{ft}$. 2 lbs.
Cucumbers in drills......5 lbs.

Egg Plant, plants $3 \times 2 \mathrm{ft}$. $.50 z$.

Endive in drills $21 \%$ ft.................................... Kale, German greens....5 lbs. Lettuce, in rows $21 / 2$ ft...................................

Leek in rows $2 \frac{1}{2} \mathrm{ft} . . . .4 \mathrm{lbs}$.

Melon, musk, in hills $4 \mathrm{x} 4$ ft.............................. 3 lbs.

Melon, water, in hills Sx8 ft...........................

Okra in drills $21 / 2 \times 4$ ft.................................... lbs

Onions in rows for sets.. $60 \mathrm{lbs}$.

Onions in rows to make large bulbs......4 lbs.

Parsnips in drills $21 / 2$ ft...........................

Pepper Plants, 21/4x1 ft.

17,500
Pumpkin, in hills

8x8 ft.........................3 lbs. Parsely, indrills $2 \mathrm{ft} . . .5$ lbs. Peas, in drills, short varieties ...................2 bu.

Peas, in drills, tall varieties........1 to $1 \frac{1}{2}$ bu.

Potatoes ........................... Radish, in drills 2 ft.....6 lbs. Salsify, in drills $21 / 2$ ft. $15 \mathrm{lbs}$

Spinach, broadcast.....30 lbs, Squash, bush, in hills $4 \mathrm{x} 4$ ft........................ 4 lbs.

Squash, running, in hills, 8x8 ft................ lbs Turnip, in drills, 2 ft....2 $\mathrm{lbs}$ Turnip, broadcast........3 lbs. Tomato, in frame..........2 oz. Tomato, seed in hills $4 \mathrm{x} 4 \mathrm{ft}$.

.8 oz.

Tomatoes, plants

3,800

\section{QUNATITY OF SEED TO SOW A SINGLE ROW}

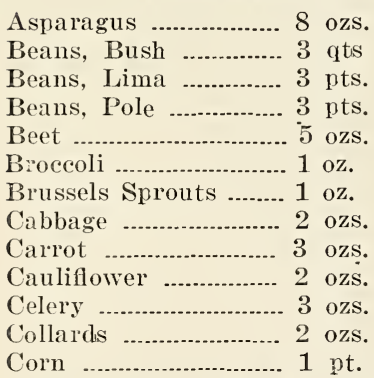

Cress ............................ 4 ozs.

Cucumber ................... 4 ozs.

Dandelion .................... 3 ozs.

Egg Plant ..................... 1 oz.

Endive ........................ 2 ozs.

Kohl Rabi ................... 2 ozs.

Leek ............................. 2 ozs

Lettuce ......................... 2 ozs.

Melon. Musk .............. 2 ozs.

Melon, Water ............ 3 ozs.

IIustard ........................ 4 ozs.

Okra ........................... 2 ozs.

Onion (large bulbis).... 2 ozs.

\section{OF 100 YARDS}

Onions (for sets) ........ 8 ozs. Paisley ....................... 2 ozs. Parsnip ....................... 3 ozs. Peas ............................... 2 qts. Pepper ........................ $1 \mathrm{oz}$.

Pumpkin .................... 2 ozs. Radish ....................... 6 ozs. Rhubarb ..................... 4 ozs. Salsify _....................... 4 ozs. Spinach ......................... 6 ozs.

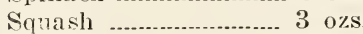
Tomato ........................ $1 \mathrm{oz}$.

Turnip …....................... 3 ozs.

ANOUNT OF FIELT GPASS SEMD NECESSARY FOR AN ACRE, AND NUMBER OF POUNDS TO PUSHEL

No. lbs. No. lbs.

to bu. to acre.

Red Clover

$60 \quad 12$ to 15

White Dutch Clover ............60

Alfalfa

5 to 8

20 to 30

5 to $\mathrm{S}$

10 to 15

24 to 36

25 to 50

10 to 15

28 to $4 \%$

14 to 42

25 to 30

40 to 70
No. lbs. No. lbs, to bu. to acre.

Hemp .44

Flax 3) to (i) 28 to 42 25 to 50 22 to 28 32 to $9 \%$ 65 to $96^{\circ}$ 8 to 10 56 to 72 60 to 90

6 to 8

50 to 75 90 to 120 


\section{SURE CROP FIELD CORN}

Every farmer is interested in Field Corn.

He wants certain characteristics in corn which will make a çrop consistently year after year.

We have those corns which have done this. Below is the list.

We will gladly send you a sample of any one or all on request.

\section{IOWA SILVER MINE}

Grown in Noble County for nine years. Has never failed to make a crop of from fifteen to forty bushels since we brought the corn to this country.

A pure white corn, ear ten inches long, medium deep grain, sixteen rows to the ear.

\section{This Corn Has Never Failed}

Our absolutely pure seed, hand tipped and nubbed, $\$ 3.00$ per bushel

\section{BLUE DENT SQUAW}

We got the seed for this good corn four years ago. It made corn one of the worst years ever experienced in Oklahoma for a corn crop. Ear ten inches long, sixteen rows of grain to the ear; grain medium deep, soft, good feeding quality, color ranging from deep blue to white and blue grains. This is not the hard, flinty old type of long slender ear Squaw Corn, but is a distinet type You will like it. Our seed is nubbed and tipped by hand, ready for the planter.

$\$ 3.00$ per bushel, f. o. b. Perry, Oklahoma.

\section{EARLY GOLDEN}

This corn has been grown in Noble County for five years. A very deep yellow, broad grain, pure red cob, not larger than the cob of pop corn, carrying eight to ten rows to the cob. Grown on upland where other corns fail, it has consistently made from fifteen to twenty-five bushels to the acre. $A$ splendid feeding corn, soft grain, maturing in 75 to 85 days, out of the soft stage by the first week in July. This corn is a real money erop year after year. Farmers in the northern part of this country swear by "EARLY GOLDEN." Our seed stock it limited. Don't fail to order early.

Pure hand tipped, nubbed and recleaned, $\$ 3.00$ per bushel. 